\title{
U-Pb Ages, Pb-Os Isotope Ratios, and Platinum-Group Element (PGE) Composition of the West-Central Madagascar Flood Basalt Province
}

\author{
Ciro Cucciniello, Antonio Langone, ${ }_{1}^{1}$ Leone Melluso, ${ }^{2}$ Vincenzo Morra, \\ John J. Mahoney, ${ }^{3}$ Thomas Meisel, ${ }^{4}$ and Massimo Tiepolo ${ }^{1}$ \\ Dipartimento di Scienze della Terra, Università di Napoli Federico II, \\ via Mezzocannone 8, 80134 Napoli, Italy \\ (e-mail: ciro.cucciniello@unina.it)
}

\begin{abstract}
A B S T R A C T
The Mailaka lava succession (central-western Madagascar) forms part of the Madagascar large igneous province and is characterized by basaltic to picritic basalt lava flows and minor evolved flows. In situ U-Pb dating of zircon in rhyodacites yields concordant ages of $89.7 \pm 1.4$ and $90.7 \pm 1.1 \mathrm{Ma}$. Therefore, the capping rhyodacitic unit of the Mailaka lava succession was emplaced just after the underlying basalt sequence (dated paleontologically at ConiacianTuronian). Two geochemically different lava series are present. A transitional series ranging from picritic basalts to basalts has incompatible element abundances and $\mathrm{Pb}, \mathrm{Os}$, and $\mathrm{Nd}$ isotope ratios within the range of mid-ocean ridge basalts. In addition, the concentrations of platinum-group elements (Ir $<0.35 \mathrm{ng} / \mathrm{g}, \mathrm{Ru}<0.17 \mathrm{ng} / \mathrm{g}, \mathrm{Pd}=1.0-1.6 \mathrm{ng} /$ $\mathrm{g}$ ) in the transitional basalts are generally lower than in basaltic lavas from oceanic plateaus (e.g., Ontong Java and Kerguelen) and other continental flood basalt provinces (e.g., Deccan and Etendeka). A tholeiitic series ranges from picritic basalts to rhyodacites and has relatively high concentrations of trace elements (e.g., $\mathrm{Rb}, \mathrm{Ba}$, Th, and light lanthanides) and the $\mathrm{Pb}-\mathrm{Sr}-\mathrm{Nd}$ and Os isotopic characteristic of magmas that have assimilated continental crust. The $\mathrm{Pb}$ isotope ratios of tholeiitic andesites indicate the involvement of a component highly depleted in radiogenic $\mathrm{Pb}$, very likely old lower crust. Energy-constrained-assimilation-fractional-crystallization modeling indicates that the rhyodacites may be the result of $\sim 25 \%$ assimilation of upper continental crust, with a ratio between assimilated mass and subtracted solid of $\sim 0.35$. An andesite with low $\mathrm{Pb}$ isotope ratios may be the result of $\sim 8 \%$ assimilation of lower continental crust with a mass assimilated/mass accumulated ratio of $\sim 0.1$. Interaction of mantle-derived magmas with crustal lithologies of different age and evolutionary history thus occurred in this sector of the flood basalt province. Contamination of mantle-derived rocks by material of different crustal domains is a process also observed in other large igneous provinces, such as the Deccan Traps.
\end{abstract}

Online enhancement: tables.

\section{Introduction}

The Madagascan large igneous province (LIP) represents one of the major magmatic events in the Late Cretaceous. Its formation is related to the breakup of Madagascar and greater India (e.g., Mahoney et al. 1991, 2008; Dostal et al. 1992; Rad2010 .

Manuscript received October 14, 2009; accepted March 28,

${ }^{1}$ Istituto di Geoscienze e Georisorse-Consiglio Nazionale delle Ricerche, Pavia, Italy.

${ }^{2}$ Author for correspondence; e-mail: melluso@unina.it.

${ }^{3}$ School of Ocean and Earth Science and Technology, University of Hawaii at Manoa, Honolulu, Hawaii 96822, U.S.A

${ }^{4}$ General and Analytical Chemistry, Montanuniversität Leoben, Austria. hakrishna et al. 1994, 1999; Storey et al. 1995, 1997; Melluso et al. 1997, 2009; Torsvik et al. 1998, 2000). Cretaceous igneous rocks crop out semicontinuously along the west, south, and east coasts of Madagascar as well as on the high plateau of the island's interior (fig. 1). They are most voluminous in the caldera of Androy (in the south) and the Mahajanga Basin (in the northwest). Lesser amounts crop out in the southern Morondava Basin and in some districts along the east coast (e.g., Sambava).

Recent geochronological data (U-Pb on zircons and ${ }^{40} \mathrm{Ar}-{ }^{39} \mathrm{Ar}$ ) show that the Madagascan province spans ages between 92 and $84 \mathrm{Ma}$ (Storey et al. 1995; Torsvik et al. 1998, 2000; Melluso et al. 2005;

[The Journal of Geology, 2010, volume 118, p. 523-541] @ 2010 by The University of Chicago. All rights reserved. 0022-1376/2010/11805-0005\$15.00. DOI: 10.1086/655012 

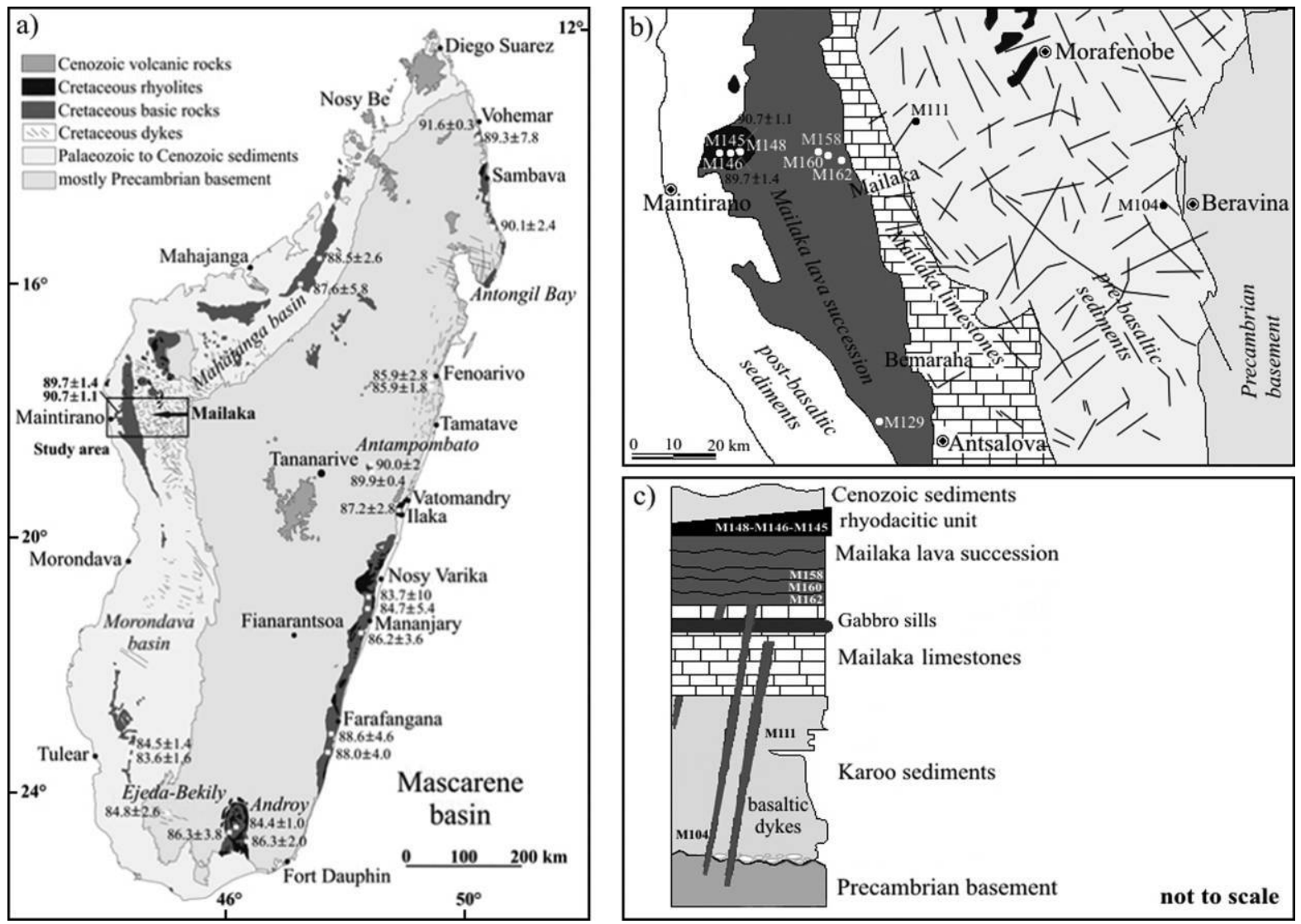

Figure 1. a, Geological sketch map of Madagascar. Outcrops of Cretaceous mafic rocks are shown in dark gray, whereas Cretaceous silicic rocks are indicated in black. Radiometric ages are also shown (see text for references). $b$, Sketch map of central-western Madagascar (after Besairie 1964) with locations of samples. $c$, Stratigraphic section (not to scale) of the Mailaka area.

Mahoney et al. 2008). Magmatism of the same age is preserved in southern India (Radhakrishna et al. 1994, 1999; Torsvik et al. 2000; Pande et al. 2001). The Madagascan LIP consists of lava flows, dikes, sills, and intrusive complexes. The chemical composition of igneous rocks is broadly bimodal, with predominant mafic and subordinate silicic rocks. Available chemical and isotopic data show that both mantle and continental crust have played a key role in the genesis and evolution of the Madagascan LIP (Mahoney et al. 1991, 2008; Melluso et al. 1997, 2001, 2002, 2003, 2005; Storey et al. 1997). However, a determination of the influence of a Marion plume component on the geochemical characteristics of the mantle-derived magmas of this igneous province remains elusive.

Results of a detailed study of the volcanic succession on the western margin of the Morondava basin were reported by Melluso et al. (2001) and will be summarized here only briefly. These au- thors recognized two different magma series: (1) a transitional series (with a few percent normative nepheline or hypersthene and with Ti-rich clinopyroxene) ranging from picritic basalt to basalt and (2) a tholeiitic series (with augite and pigeonite) ranging from picritic basalt to rhyodacite. The transitional series shows chemical and isotopic characteristics inherited from an incompatibleelement-depleted, mid-ocean ridge basalt (MORB)like mantle source. In contrast, the volcanic rocks of the tholeiitic series are probably the product of extensive fractional crystallization and crustal contamination. In this article, we present in situ U-Pb dates on zircons and new bulk-rock $\mathrm{Pb}-\mathrm{Os}$ isotopic data on the volcanic rocks of the Mailaka area, integrating and extending the work of Melluso et al. (2001). These rocks provide insights into the relative timing of the silicic magmatism and interaction between mantle-derived melts and continental crust. 

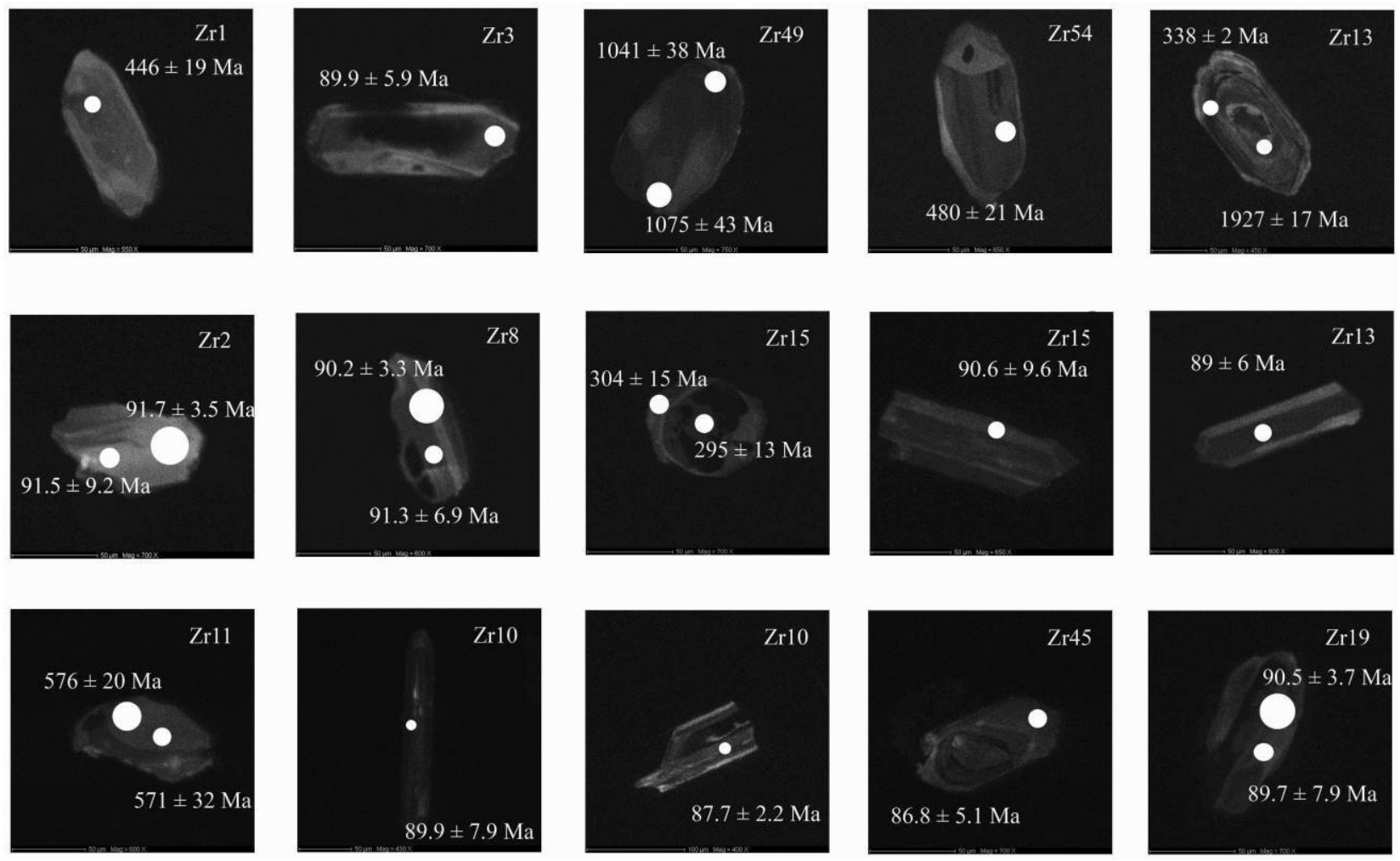

Figure 2. Representative cathodoluminescence images of zircon grains from the Mailaka rhyodacites. The location of spots and U-Pb ages with $2 \sigma$ errors are shown.

\section{Geological Setting and Petrography of the Samples}

The Mailaka lava succession covers a large area in central-western Madagascar, along the rifted margin of the Morondava basin. An 40-km-long section is exposed (fig. 1a). It consists of an $\sim 150-\mathrm{m}-$ thick section of lava flows (with columnar jointing) that gently dip westward, with some 17 different flow units usually separated by thick hydrothermal deposits, paleosoil, and altered pyroclastic rocks. Two basalt types have been found as interlayered flows and in the dike swarm (table A1, available in the online edition or from the Journal of Geology office): (1) transitional basalts (or weakly alkaline basalts) are relatively rare and have olivine, titaniferous diopside-hedenbergite, and plagioclase phenocrysts in a groundmass with the same minerals and Fe-Ti oxides; (2) the dominant tholeiitic basalts have olivine, augite-Fe-augite, and plagioclase in a groundmass with additional $\mathrm{Fe}-\mathrm{Ti}$ oxides and pigeonite (full information in Melluso et al. 2001, 2006b). The lava succession covers the Early Cretaceous Mailaka Limestone Formation (fig. $1 c$; Besairie and Collignon 1972). Dacitic fand rhyodacitic lavas (pitchstones) are volumetrically minor and crop out east of Maintirano (fig. 1b, 1c). These rocks contain phenocrysts of relatively calcic plagioclase, cordierite, orthopyroxene, ilmenite, fayalitic olivine, quartz, and accessory minerals in abundant glass (Melluso et al. 2001, 2006b; table A2, available in the online edition or from the Journal of Geology office). Toward the south, the succession appears to decrease in thickness, and rhyodacitic flows are absent. No radiometric ages are available for the basaltic sequence, but the biostratigraphic age is Coniacian-Turonian (Besairie and Collignon 1972). Dikes cut the Permo-Triassic to Cretaceous sedimentary rocks of the Morondava basin, up to the boundary with the Precambrian basement, crossing which they disappear. The dikes reach 10 $\mathrm{m}$ in width, are randomly oriented, and often cross cut each other. Olivine-bearing gabbroic sills intrude the Mailaka Limestone Formation. The Precambrian basement of the area consists of $\sim 2.5-\mathrm{Ga}$ gneiss interlayered with 820-740-Ma granitoids and gabbros that were pervasively deformed and metamorphosed to granulite-facies between $\sim 750$ and $500 \mathrm{Ma}$ (Ashwal and Tucker 1997; Tucker et 
al. 1999b; Kröner et al. 2000). The Mesoproterozoic to Neoproterozoic metamorphic rocks consist of dolomitic marbles, quartzites, and metapelites deposited between 1855 and $804 \mathrm{Ma}$ (Cox et al. 1998; Handke et al. 1999) and subsequently deformed and intruded by gabbros and syenites.

\section{Geochronology: Previous Work}

K-Ar whole-rock ages for lavas and dikes of the Madagascan province were published by Storetvedt et al. (1992) and Dostal et al. (1992). Storetvedt et al. (1992) reported K-Ar ages as old as $94.5 \pm 1.2$ Ma for dolerite dike samples from eastern Madagascar. Dostal et al. (1992) obtained K-Ar ages between 31 and $79 \mathrm{Ma}$ for mafic lavas and dikes in the southern part of the island. The samples probably suffered Ar loss during alteration (Dostal et al. 1992). Storey et al. (1995) reported 17 age determinations for basalts and rhyolites samples from the rifted eastern margin, the Mahajanga and Morondava basins, and southern Madagascar (Volcan de l'Androy complex and the Ejeda-Bekily dike swarm), using ${ }^{40} \mathrm{Ar}^{39} \mathrm{Ar}$ whole-rock step heating and the laser fusion method on single and multiple feldspar grains. A whole-rock $\mathrm{Rb}$-Sr isochron age of $84 \pm 2.4 \mathrm{Ma}$ has been also reported for rhyolites of the Androy complex (Mahoney et al. 2008). The ${ }^{40} \mathrm{Ar}^{-39} \mathrm{Ar}$ ages for the volcanic rocks and dikes of the eastern margin are between 84 and $90 \mathrm{Ma}$, with a weighted mean age of $87.6 \pm 0.6 \mathrm{Ma}$, and indicate that the Cretaceous magmatism first ceased in the northern part of the island. U-Pb zircon ages reported by Torsvik et al. (1998) and Melluso et al. (2005) for the Analalava gabbro intrusion (northeast Madagascar) and Antampombato-Ambatovy complex (central-eastern Madagascar) indicate intrusion ages of $91.6 \pm 0.3 \mathrm{Ma}$ and $90.0 \pm 2.0 \mathrm{Ma}$, respectively.

\section{Analytical Procedures}

The samples used in this work are a selection of those studied by Melluso et al. (2001). The mafic rocks are tholeiitic and transitional basalt lava flows (M129, M158, and M162) and dikes (M104 and M111). The intermediate-evolved rocks are andesite (M145 and M160) and rhyodacite (M146 and M148) lava flows that crop out along the central Mailaka section. $\mathrm{Pb}$ isotope analyses were obtained at School of Ocean and Earth Sciences and Technology, University of Hawaii, following the methods described by Mahoney et al. (1991, 1992). Sample chips were leached briefly in a weak $\mathrm{HF}: \mathrm{HNO}_{3}$ mixture and dissolved successively in $\mathrm{HF}-\mathrm{HNO}_{3}$, $\mathrm{HNO}_{3}$, and $\mathrm{HCl}$, with dry-down steps in between. A split of each solution was spiked with ${ }^{206} \mathrm{~Pb}$. Lead was subsequently separated in both the spiked and unspiked splits in a two-step elution with mixed $\mathrm{HBr}-\mathrm{HNO}_{3}$ on $100-\mu \mathrm{L}$ anion exchange columns. Mass spectrometric measurements were performed on a VG Sector multicollector mass spectrometer. Total procedural blanks for $\mathrm{Pb}$ were $<19 \mathrm{pg}$.

Rhenium, osmium, and platinum-group element (PGE) concentration determinations were performed on whole rocks, following the methods described by Meisel et al. (2001). Os and Re isotope compositions were measured on a Finnigan MAT 262 at the Centre National de la Recherche Scientifique-Centre de Recherches Pétrographiques et Géochimiques in Nancy, France, in negative thermal ionization mode (Meisel et al. 2001, 2003; Reisberg et al. 2002).

Zircon crystals for U-Pb dating were separated from two rhyodacites (M146 and M148) using a Frantz magnetic separator and heavy liquids and then mounted in epoxy and polished to $20 \mu \mathrm{m}$ thick. Back-scattered electron and cathodoluminescence (CL) images were acquired at the Consiglio Nazionale delle Ricerche (CNR) Istituto di Geoscienze e Georisorse, Sezione di Pavia. In situ $\mathrm{U}-\mathrm{Pb}$ isotopic measurements were carried out by laser ablation inductively coupled plasma-mass spectrometry at the CNR Istituto di Geoscienze e Georisorse, Sezione di Pavia. The laser ablation instrument couples an ArF excimer laser microprobe at $193 \mathrm{~nm}$ (Microlas Geolas 200Q) with a Thermo Finnigan Element I high-resolution sector field ICPMS system. The analytical method is basically the same as described by Tiepolo (2003). Instrumental and laser-induced $\mathrm{U} / \mathrm{Pb}$ fractionation was corrected using the 1065-Ma zircon 91500 (Wiedenbeck et al. 1995) as an external calibration standard. Each analytical run included four reference materials at the beginning and four reference materials at the end of the run. The zircon 02123 (Ketchum et al. 2001) was also analyzed for quality control in each run. The spot size was set to 20 or $10 \mu \mathrm{m}$. Data reduction was carried out using the "GLITTER" software package (van Achterbergh et al. 2001). Timeresolved signals were carefully inspected to detect perturbation of the signal related to inclusions, cracks, or mixed-age domains. Within the same analytical run, the error associated with the reproducibility of the external calibration was propagated to each analysis of sample (see Horstwood et al. 2003), and after this procedure each age determination is considered accurate within the quoted 

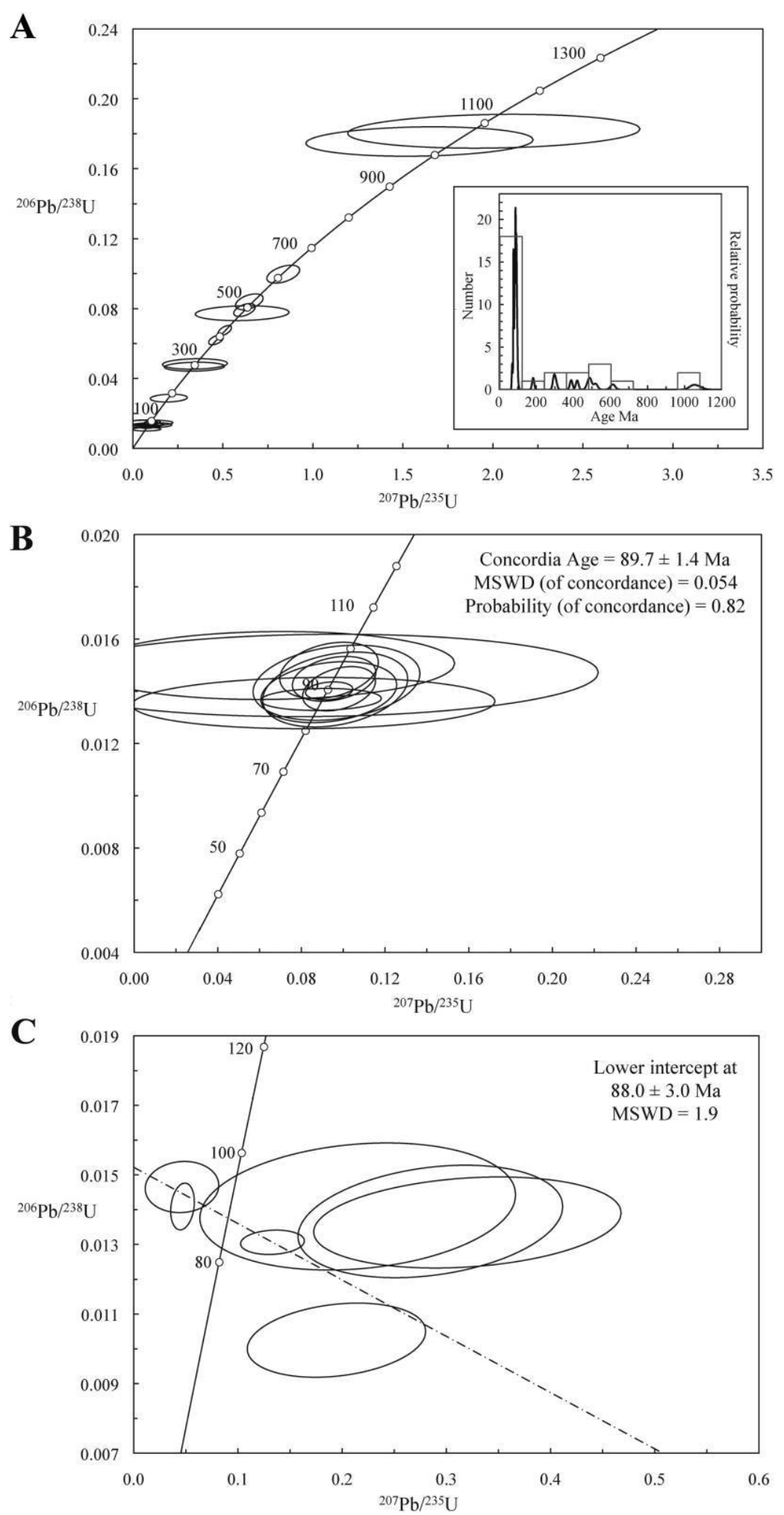

Figure 3. U-Pb ages of zircons from rhyodacite $\mathrm{M} 146: A, B,{ }^{206} \mathrm{~Pb} /{ }^{238} \mathrm{U}$ versus ${ }^{207} \mathrm{~Pb} /{ }^{235} \mathrm{U}$ concordia diagrams for concordant ages. In $A$, a cumulative Gaussian distribution curve is also shown. Error ellipses are $2 \sigma$. $C$, Concordia diagram of discordant data. 

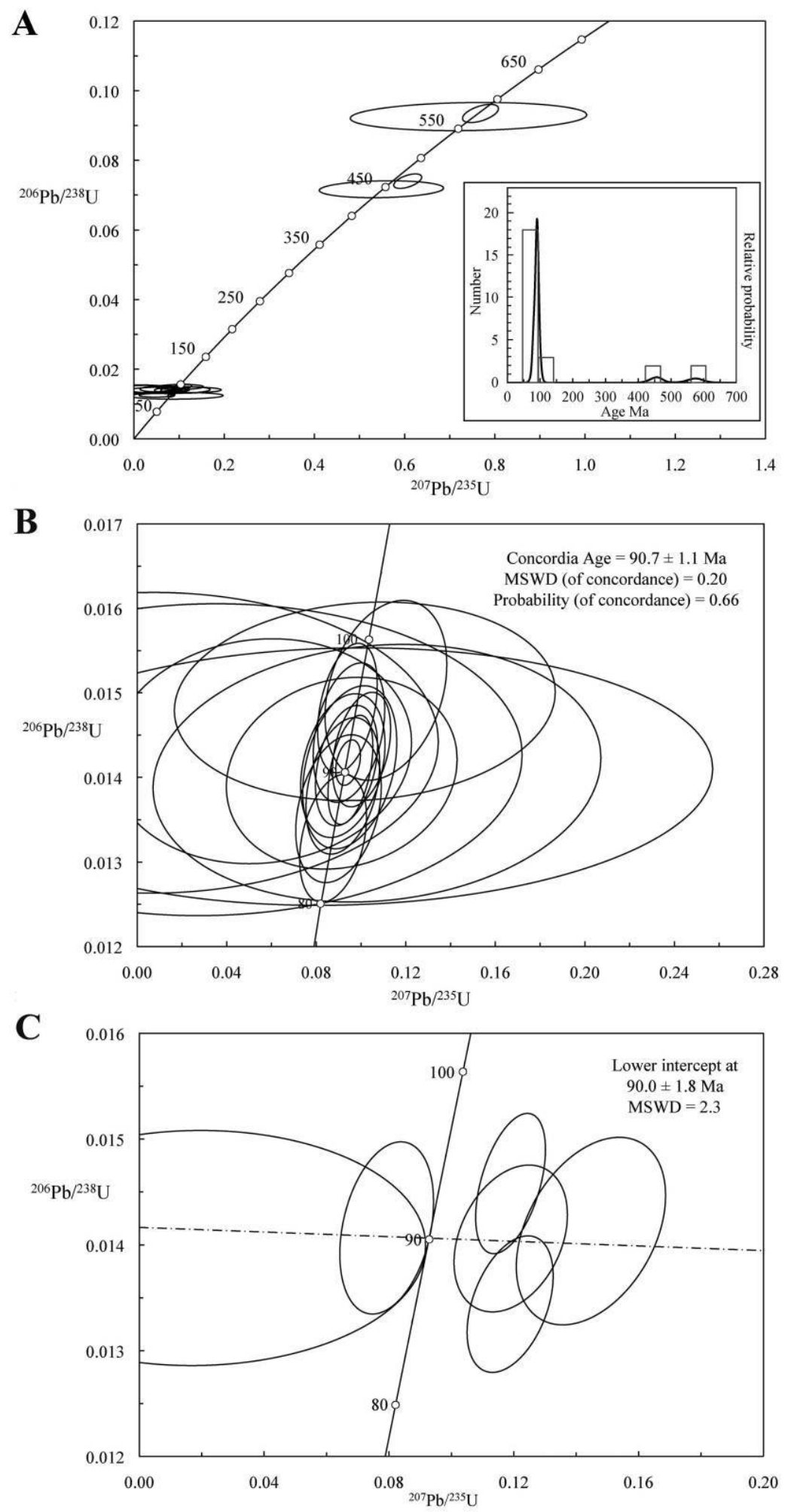

Figure 4. U-Pb ages of zircons from rhyodacite $\mathrm{M} 148: A, B,{ }^{206} \mathrm{~Pb} /{ }^{238} \mathrm{U}$ versus ${ }^{207} \mathrm{~Pb} /{ }^{235} \mathrm{U}$ concordia diagrams for concordant ages. In $A$, a cumulative Gaussian distribution curve is also shown. Error ellipses are $2 \sigma$. $C$, Concordia diagram of discordant data. 


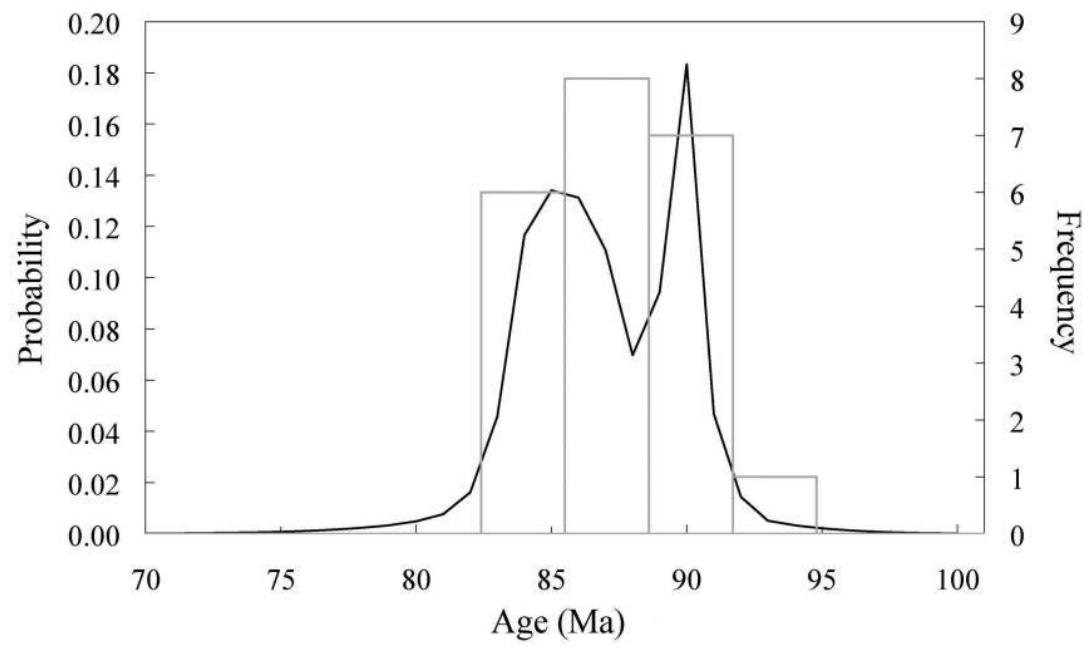

Figure 5. Age-frequency histogram and probability density distribution diagram for the Madagascan large igneous province rocks. Data sources: Storey et al. (1995); Torsvik et al. (1998); Melluso et al. (2005); this work. The probability density distribution curve was calculated following Sircombe (2004).

error. Concordia ages were determined and concordia plots were constructed using Isoplot/EX 3.0 software (Ludwig 2000).

\section{Zircon U-Pb Ages}

Zircons from rhyodacite M146 are mostly euhedral, with a prismatic habit, and are generally fractured. Most grains exhibit well-developed oscillatory zoning typical of growth under magmatic conditions (Vavra et al. 1996; fig. 2). A few zircons are characterized by dark cores and brighter rims with faint oscillatory zoning. A total of $44 \mathrm{U}-\mathrm{Pb}$ analyses were carried out on 31 zircon grains. Isotopic results gave $29 \mathrm{U}-\mathrm{Pb}$ concordia ages ranging from 70 to 1075 $\mathrm{Ma}$, with a major cluster between 84 and $96 \mathrm{Ma}$ (fig. $3 A$; table A3, available in the online edition or from the Journal of Geology office). This cluster shows a mean concordia age of $89.7 \pm 1.4 \mathrm{Ma}$ $(\mathrm{MSWD}=0.054$; probability of concordance $=$ 0.82; table A3; fig. $3 \mathrm{~B}$ ). The oldest concordant ages (183-1075 Ma) belong to inherited zircons, whereas the youngest (70-82 Ma), mainly obtained from fractured zircons, are probably related to variable $\mathrm{Pb}$ loss. The linear regression on a concordia diagram of seven discordant ages showing the youngest ${ }^{206} \mathrm{~Pb} /{ }^{238} \mathrm{U}$ ages (fig. $3 C$; table $\mathrm{A} 3$ ) yields a lower intercept age of $88.0 \pm 1.3(\mathrm{MSWD}=1.9)$, which is identical within error to the concordia age.

A total of $35 \mathrm{U}-\mathrm{Pb}$ analyses were performed on 25 zircon grains from rhyodacite M148. The results are mostly concordant (25 analyses; table A3) and range between 79 and $576 \mathrm{Ma}$. Eighteen concordant data points yield ages of $90.7 \pm 1.1 \mathrm{Ma}$ (probability of concordance $=0.66$; fig. $4 A$ ). The linear regression on a concordia diagram (fig. $4 B$ ) of six discordant ages, showing the youngest ${ }^{206} \mathrm{~Pb} /{ }^{238} \mathrm{U}$ ages, yielded a lower intercept age of $90.0 \pm 1.8$ (MSWD = 2.3; fig. 4C). The lower intercept age is consistent with the age of the concordant data. The youngest concordant ages (79-80 Ma) are probably due to minor $\mathrm{Pb}$ loss. The oldest concordant ages (446-576 Ma) belong to zircon grains inherited from the underlying crust.

The U-Pb data obtained in this study show a very consistent pattern of high-precision ages. The age determinations obtained from two rhyodacites are identical within error with the U-Pb age of the Analalava gabbro and Antampombato-Ambatovy complex (see above).

\section{Age and Duration of the Madagascar Magmatic Event}

Storey et al. (1995) argued that the entire duration of Cretaceous volcanism on the island was no more than 6 m.yr. More recently, Torsvik et al. (1998) argued that the Cretaceous magmatism started as early as $91.6 \pm 0.3 \mathrm{Ma}$ and that the Analalava gabbro intrusion probably represents the magma chamber for basaltic and rhyolitic volcanic rocks in eastern Madagascar. Figure 5 illustrates the age frequency histogram with probability density distribution for Madagascar samples. The entire dataset (previous and new results) defines a large concentration of ages between 84 and $92 \mathrm{Ma}$, 


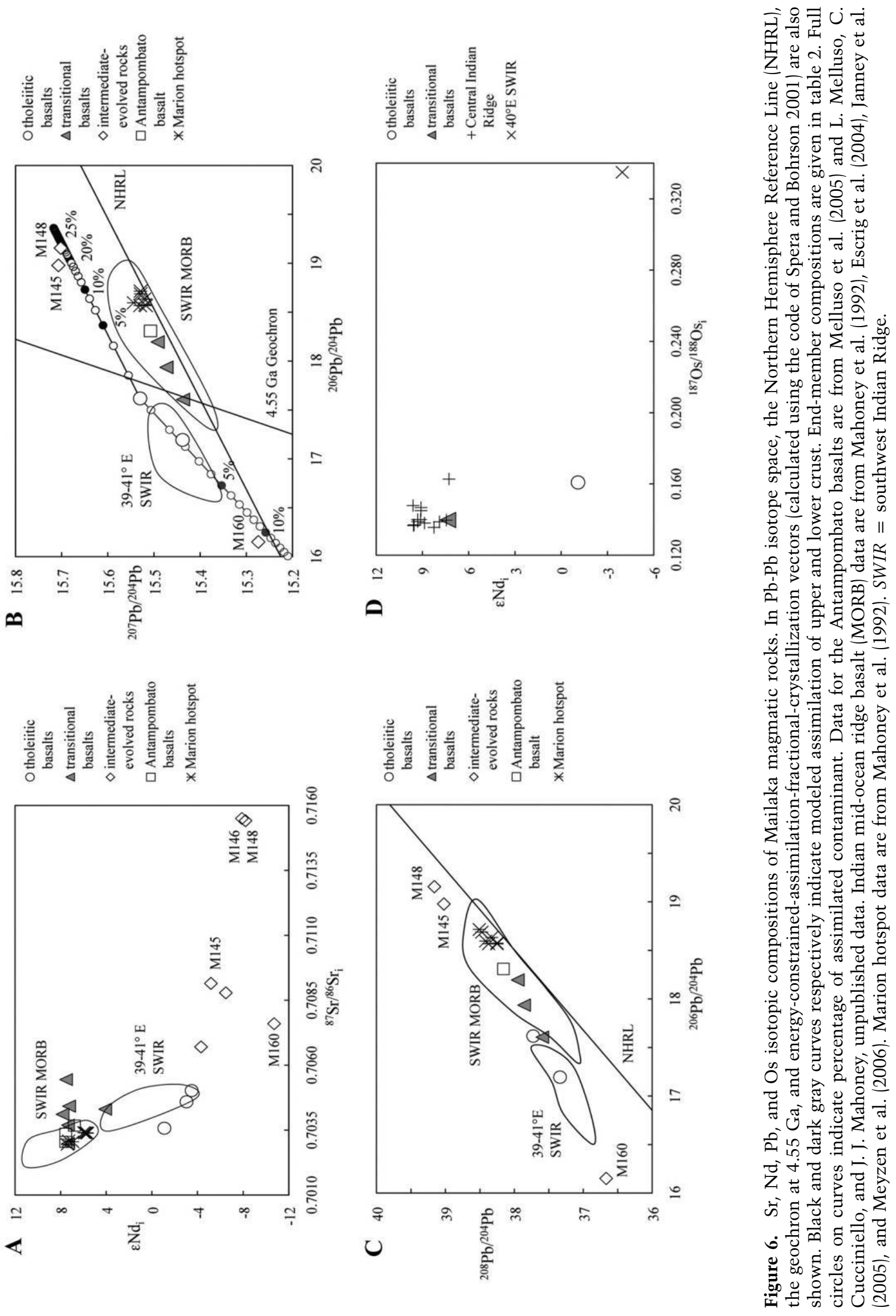

This content downloaded from 159.149.193.219 on August 31, 2017 00:45:58 AM 
Table 1. Re-Os Isotopic Data and Platinum-Group Element Concentrations of Mafic Rocks

\begin{tabular}{|c|c|c|c|}
\hline Sample series type & $\begin{array}{c}\text { M111 transitional } \\
\text { basalt }\end{array}$ & $\begin{array}{l}\text { M158 transitional } \\
\text { picritic basalt }\end{array}$ & $\begin{array}{l}\text { M162 tholeiitic } \\
\text { picritic basalt }\end{array}$ \\
\hline$\overline{\mathrm{Re}}$ & .935 & .860 & .204 \\
\hline Os & .069 & .863 & .028 \\
\hline $\mathrm{Ru}$ & .140 & .169 & \\
\hline $\mathrm{Pd}$ & .974 & 1.642 & \\
\hline Ir & .107 & .301 & \\
\hline $\mathrm{Pt}$ & 1.194 & 2.286 & \\
\hline${ }^{187} \mathrm{Re} /{ }^{188} \mathrm{Os}$ & 66.1 & 26.1 & 35.3 \\
\hline${ }^{187} \mathrm{Os} /{ }^{188} \mathrm{Os}$ & .2380 & .1789 & .2139 \\
\hline${ }^{187} \mathrm{Os} /{ }^{188} \mathrm{Os}_{\mathrm{i}}$ & .1389 & .1398 & .1609 \\
\hline$\gamma_{\text {Os }}$ & 9.9 & 10.6 & 27.3 \\
\hline
\end{tabular}

Note. Abundances for Re, Os, and platinum-group elements are in ng/g. $\gamma_{\text {Os }}=\left[\left({ }^{187} \mathrm{Os} /{ }^{188} \mathrm{Os}_{\text {samples }} /{ }^{187} \mathrm{Os} /{ }^{188} \mathrm{Os}\right.\right.$ mantle $)-$ 1] $\times 100$ using an estimated average chondritic mantle ${ }^{187} \mathrm{Os} /{ }^{188} \mathrm{Os}=0.127$ (Walker and Morgan 1989).

supporting a duration of magmatic activity of about 8 m.yr., with a general shift of magmatism from north to south (Storey et al. 1995). We also note that the Ar-Ar ages (90-84 Ma) are either within range of, or younger than, the U-Pb ages (92-90 Ma). In addition, the probability density distribution curve (fig. 5) shows two peaks. It is not clear whether they represent two different periods of magmatic activity or, rather, are a product of a relatively limited number of age determinations $(n=22)$.

The Late Cretaceous basaltic volcanism in Madagascar has been attributed to the ascent of the Marion plume head to the base of the Madagascan lithosphere soon before Madagascar rifted from greater India (Storey et al. 1995). The substantially random overall orientation of the dikes in the Mailaka dike swarm and the presence of several igneous intrusions in the northwestern part of the province (fig. 1) suggest that the Mailaka basalts were erupted from northwestern Madagascar. The Mailaka igneous rocks are located in the Karoo-related Morondava basin, an area where the lithosphere may previously have been thinned (Piqué et al. 1999) and beneath which melting could have taken place preferentially.

\section{Pb Isotope Composition}

$\mathrm{Pb}$ isotopic ratios of Mailaka samples (table $\mathrm{A} 4$, available online or from the Journal of Geology office), together with previously published $\mathrm{Sr}-\mathrm{Nd}$ isotope data (Melluso et al. 2001), are plotted in figure $6 \mathrm{~A}$. The transitional basalts show a relatively large range in ${ }^{87} \mathrm{Sr} /{ }^{86} \mathrm{Sr}_{\mathrm{i}}(0.70298-0.70545$; where $\mathrm{i}$ indicates corrected to $90 \mathrm{Ma}$ ), over a restricted range of ${ }^{143} \mathrm{Nd} /{ }^{144} \mathrm{Nd}_{\mathrm{i}}\left(0.51273-0.51291 ; \varepsilon \mathrm{Nd}_{\mathrm{i}}=+4.1\right.$ to +7.8 ). The large range in ${ }^{87} \mathrm{Sr} /{ }^{86} \mathrm{Sr}_{i}$ is very likely due to the influence of seawater (see "Analytical Methods" in Melluso et al. 2001). The Pb isotope ratios of all but one of the transitional basalts, even though not age corrected, exhibit only a small variation in ${ }^{206} \mathrm{~Pb} /{ }^{204} \mathrm{~Pb}(17.936-18.195),{ }^{207} \mathrm{~Pb} /{ }^{204} \mathrm{~Pb}$ (15.473-15.492), and ${ }^{208} \mathrm{~Pb} /{ }^{204} \mathrm{~Pb}(37.858-37.951)$. Sample M104 has lower ${ }^{206} \mathrm{~Pb} /{ }^{204} \mathrm{~Pb}(17.606),{ }^{208} \mathrm{~Pb} /$ ${ }^{204} \mathrm{~Pb}(37.594)$, and ${ }^{207} \mathrm{~Pb} /{ }^{204} \mathrm{~Pb}$ (15.437) than the other transitional basalts but similar $\varepsilon \mathrm{Nd}_{\mathrm{i}}(+7.4$; fig. $6 A-6 C$ ). In $\mathrm{Pb}-\mathrm{Pb}$ isotope space (fig. $6 B, 6 C$ ), data for the transitional basalts overlap the field defined by Indian MORB and Antampombato basalt (Mahoney et al. 1989, 1992; Janney et al. 2005; Meyzen et al. 2006; L. Melluso, C. Cucciniello, and J. J. Mahoney, unpublished data). The tholeiitic basalts display similar radiogenic ${ }^{87} \mathrm{Sr} /{ }^{86} \mathrm{Sr}_{\mathrm{i}}(0.70357-$ $0.70502)$ but less radiogenic ${ }^{143} \mathrm{Nd} /{ }^{144} \mathrm{Nd}_{\mathrm{i}}(0.51235-$ $0.51247 ; \varepsilon \mathrm{Nd}_{\mathrm{i}}=-1.1$ to -3.5 ; fig. $6 \mathrm{~A}$ ) than the transitional basalts. In figure $6 B, 6 C$ the data plot to the left of the 4.55-Ga geochron and above the Northern Hemisphere Reference Line (Hart 1984). The tholeiitic basalts have $\mathrm{Sr}-\mathrm{Nd}$ and $\mathrm{Pb}$ isotopic ratios comparable with those of basalts recovered in the $39^{\circ}-41^{\circ} \mathrm{E}$ sector of the southwest Indian Ridge (Mahoney et al. 1992; Janney et al. 2005; Meyzen et al. 2006). The intermediate to evolved rocks span a wide range of isotopic values, all but one having negative $\varepsilon \mathrm{Nd}_{\mathrm{i}}(-4.3$ to -8.2$)$ and high ${ }^{87} \mathrm{Sr} /{ }^{86} \mathrm{Sr}_{\mathrm{i}} \quad(0.70879-0.71550),{ }^{206} \mathrm{~Pb} /{ }^{204} \mathrm{~Pb} \quad(18.978-$ 19.156), ${ }^{207} \mathrm{~Pb} /{ }^{204} \mathrm{~Pb}(15.702-15.707)$, and ${ }^{208} \mathrm{~Pb} /{ }^{204} \mathrm{~Pb}$ (39.023-39.161). In contrast, andesite M160 is markedly different in having lower ${ }^{143} \mathrm{Nd} /{ }^{144} \mathrm{Nd}_{i}$ $\left(0.51198 ; \varepsilon \mathrm{Nd}_{\mathrm{i}}=-10.7\right),{ }^{87} \mathrm{Sr} /{ }^{86} \mathrm{Sr}_{\mathrm{i}}(0.70760),{ }^{206} \mathrm{~Pb} /$ ${ }^{204} \mathrm{~Pb}(16.151),{ }^{207} \mathrm{~Pb} /{ }^{204} \mathrm{~Pb}(15.274)$, and ${ }^{208} \mathrm{~Pb} /{ }^{204} \mathrm{~Pb}$ (36.668). In $\mathrm{Pb}-\mathrm{Pb}$ isotope space (fig. 6B), data for sample M160 plot to the left of the 4.55-Ga geochron, whereas data for the other intermediate to evolved rocks plot to the right.

\section{Os Isotopes and Platinum-Group Elements}

Re-Os isotopic data are reported in table 1 . The tholeiitic basalt M162 has low Os $(0.028 \mathrm{ng} / \mathrm{g})$ and 

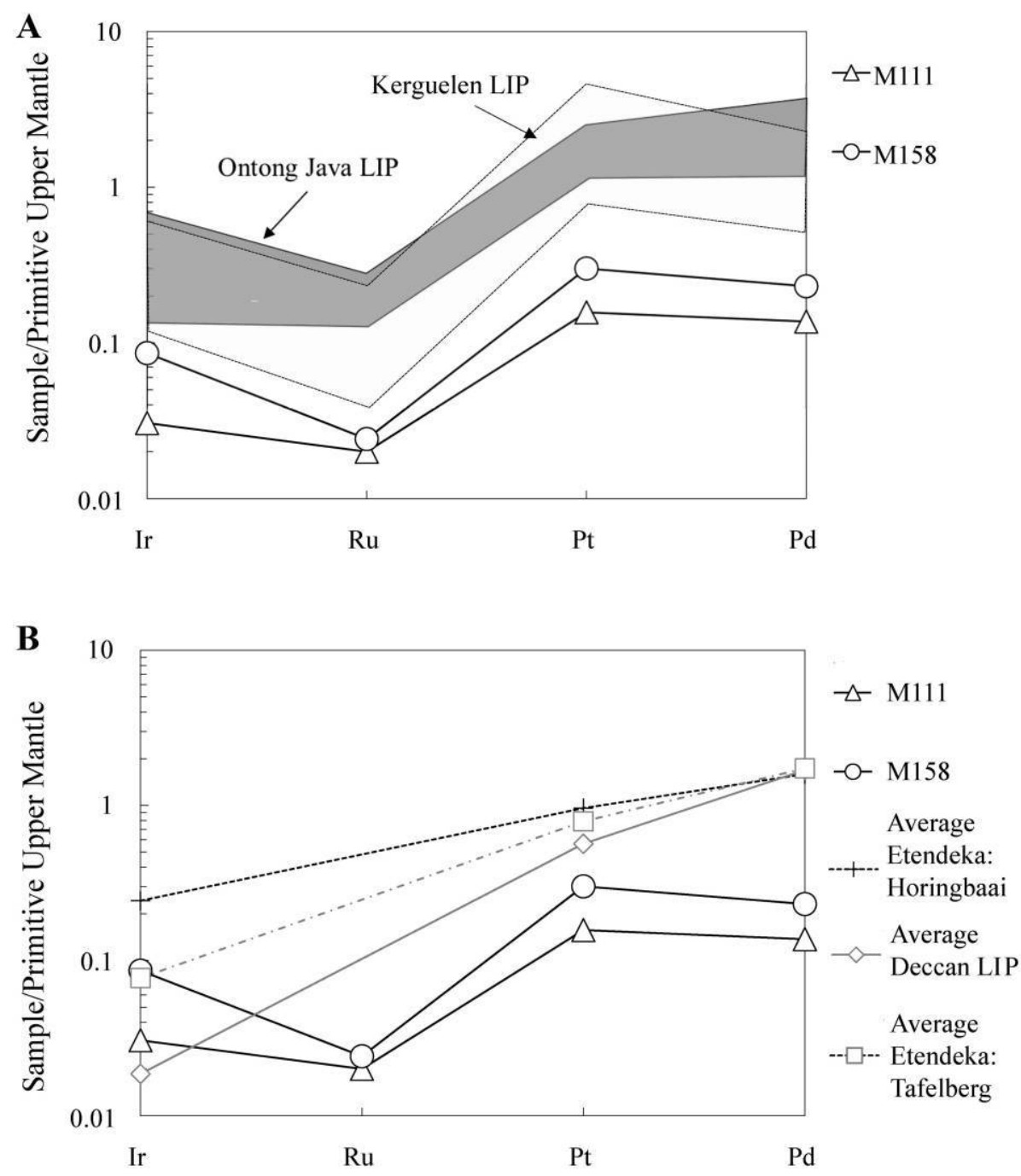

Figure 7. Primitive-mantle-normalized platinum-group element abundances for the transitional basalts of Mailaka. Data for Ontong Java Plateau, Kerguelen Plateau, Etendeka, and Deccan basaltic rocks are from Maier et al. (2003), Chazey et al. (2004, 2005), and Crocket et al. (2004). Primitive mantle values are from Becker et al. (2006). LIP = large igneoous province.

relatively low $\operatorname{Re}(0.204 \mathrm{ng} / \mathrm{g})$ concentrations. Its Re concentration is similar to that of most oceanic island basalts but lower than the average MORB value $(\mathrm{Re}=920 \pm 340 \mathrm{pg} / \mathrm{g}$; e.g., Hauri et al. 1997; Escrig et al. 2004; Gannoun et al. 2007). The transitional basalts have significantly higher Re and Os concentrations than sample M162. Because of their variable Re and Os concentrations, the transitional basalts have ${ }^{187} \mathrm{Re} /{ }^{188} \mathrm{Os}$ ratios ranging from 26.7 to 66.1. The transitional basalts have age-corrected Os isotopic compositions $\left({ }^{187} \mathrm{Os} /{ }^{188} \mathrm{Os}_{\mathrm{i}}=0.1389\right.$ $\left.0.1398 ; \gamma_{\mathrm{Os}}=+9.9-10.6\right)$ and Re contents similar to those observed in many MORBs (e.g., Escrig et al. 2004; Gannoun et al. 2007; fig. 6D). In contrast, the tholeiitic basalt has more radiogenic Os $\left({ }^{187} \mathrm{Os} /\right.$ ${ }^{188} \mathrm{Os}_{\mathrm{i}}=0.1609 ; \gamma_{\mathrm{os}}=27.3$ ).

The PGE data for transitional basalts M111 and M158 are listed in table 1 and shown in figure $7 A$, $7 B$. These basalts exhibit a restricted range in Ir (0.11-0.30 ng/g), Ru (0.14-0.17 ng/g), Pt (1.19-2.29 $\mathrm{ng} / \mathrm{g})$, and Pd (0.97-1.64 ng/g) and have PGE patterns with broadly similar shapes (fig. $7 A, 7 B$ ), with $\mathrm{Ru} / \mathrm{Ir}$ and $\mathrm{Pt} / \mathrm{Pd}$ ratios (chondrite-normalized ratios; Anders and Grevesse 1989) slightly less than 1. Sample M158 has a slight Ru depletion in its primitive-mantle-normalized pattern (fig. $7 A, 7 B$ ). In ad- 


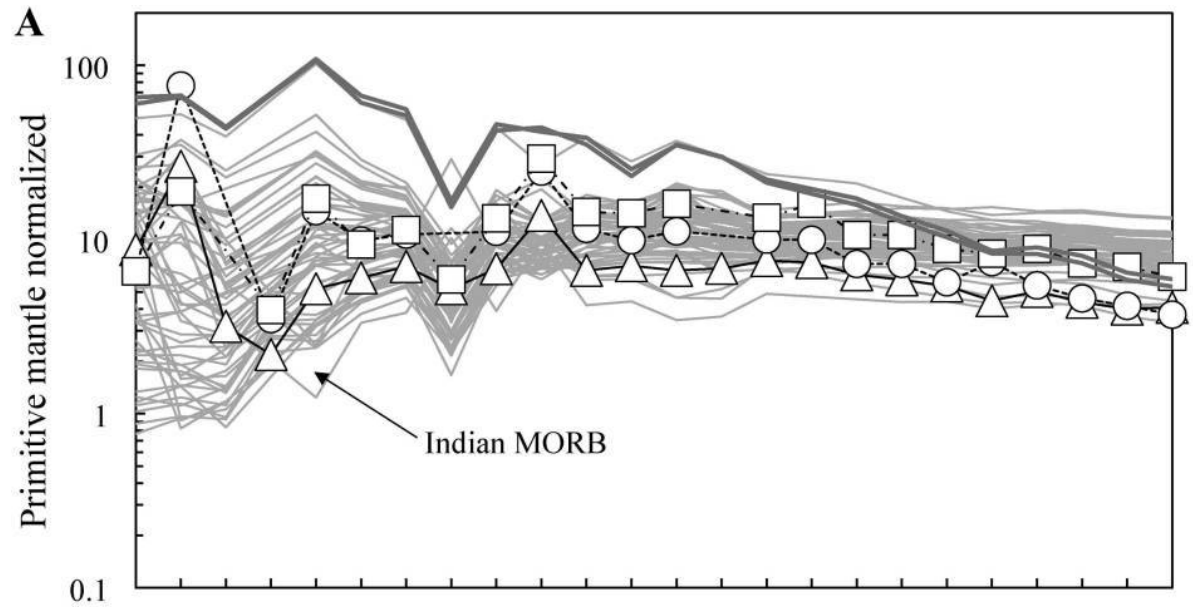

$\mathrm{Rb} \mathrm{Ba}$ Th K Nb La Ce Pb Pr Sr NdSm Zr Hf Eu Ti Gd Tb Dy Y Ho Er Yb Lu $\triangle-$ M111 --O--M158 - $\square-\mathrm{M} 104 \quad-$ Marion hotspot

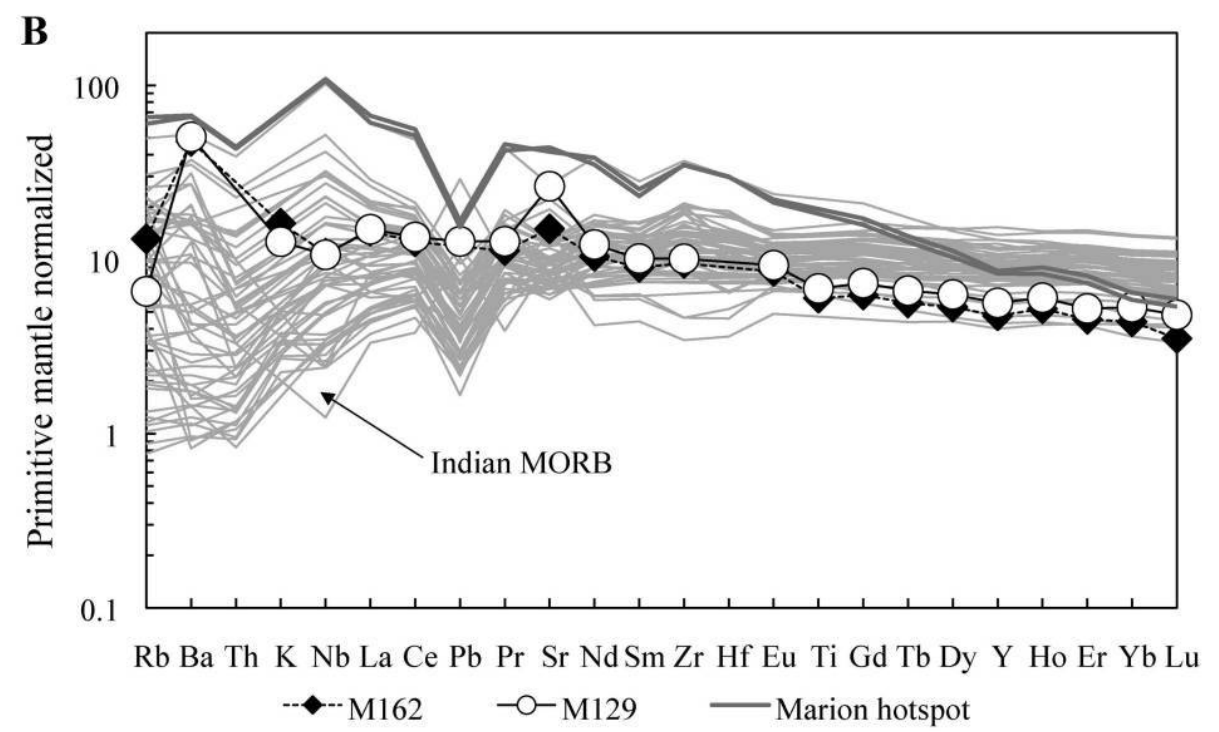

Figure 8. Primitive-mantle-normalized incompatible element patterns for transitional $(A)$ and tholeiitic $(B)$ basalts. Indian mid-ocean ridge basalt (MORB) data are from Rehkämper and Hofmann (1997) and Janney et al. (2005). Marion hotspot data are from Mahoney et al. (1992). Normalizing mantle values are after Lyubetskaya and Korenaga (2007).

dition, these two transitional basalts are characterized by low $\mathrm{Pd} / \mathrm{Ir}(5.5-9.1)$ ratios. Their low $\mathrm{Pd} /$ Ir ratios and high $\mathrm{MgO}(9.8-12.0 \mathrm{wt} \%)$ and $\mathrm{Ni}(233-$ $432 \mu \mathrm{g} / \mathrm{g}$ ) contents indicate that the transitional basalts are not very evolved. In general, the patterns are typical for basalts, showing Os, Ir, and Ru depletion relative to estimates of the primitive upper mantle and high ratios of $\mathrm{Pd}, \mathrm{Pt}$, and $\mathrm{Re}$ to Os, Ir, and $\mathrm{Ru}$ ratios. The absolute concentrations of PGE for the transitional basalts tend to be lower than those for basaltic rocks from oceanic plateaus (e.g.,
Chazey et al. 2004, 2005) and other continental flood basalt provinces (Maier et al. 2003; Crocket et al. 2004; fig. 7).

\section{Discussion}

Key questions concerning the petrogenesis of the Mailaka lava succession include the relative contributions from a plume, a nonplume asthenosphere, continental lithospheric mantle, and continental crust. The strong isotopic and petrographic 


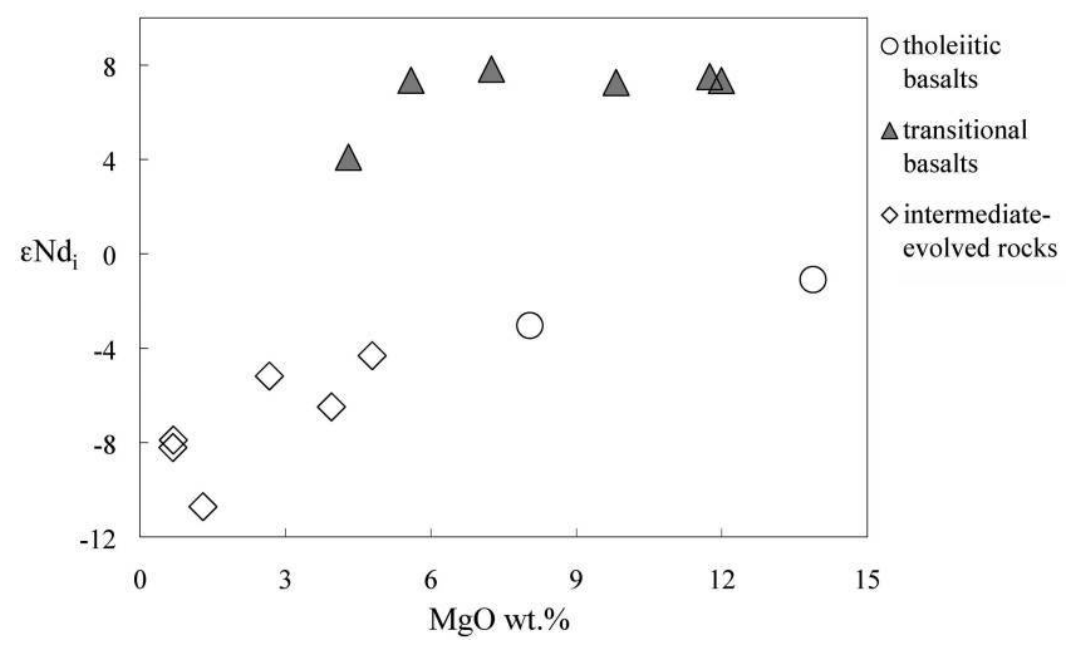

Figure 9. Initial ${ }^{143} \mathrm{Nd} /{ }^{144} \mathrm{Nd}$ initial isotopic compositions versus $\mathrm{MgO}$ for Mailaka magmatic rocks.

differences between the transitional and tholeiitic series indicate independent crystallization paths from different parental magmas. Sr and $\mathrm{Nd}$ isotopic compositions of the transitional basalts are comparable with those measured in present-day Marion hotspot lavas. In contrast, $\mathrm{Pb}$ isotopic values of the transitional basalts are lower than those of presentday Marion hotspot lavas. Mixing between small amounts of $\mathrm{Pb}$-rich, low- ${ }^{206} \mathrm{~Pb} /{ }^{204} \mathrm{~Pb}$ continental material and magma with Marion-type isotope ratios could produce the $\mathrm{Pb}$ isotope variation observed in the transitional basalts. However, mixing alone cannot explain the different concentrations of incompatible elements between the transitional basalts and present-day Marion hotspot lavas. Partial melting models indicate that present-day Marion hotspot lavas were generated from a mantle source more enriched in incompatible elements than the source of the Mailaka transitional basalts (Melluso et al. 2001, 2003). The chemical and isotopic data of the tholeiitic basalts of Mailaka suggest that the source of these rocks is probably similar to the source of MORB, with an additional, crustally derived component (Melluso et al. 2001). Interaction between an ascending mafic magma and the surrounding continental crust can contaminate the magma, although in some cases the chemical changes may be negligible. The Os isotopic ratios provide a powerful tool for distinguishing between crustal and continental lithospheric mantle signatures. Os behaves compatibly during melting or fractional crystallization, whereas Re is a mildly incompatible element, resulting in high Re/Os in melts and low $\mathrm{Re} / \mathrm{Os}$ in the mantle residue (e.g.,
Shirey and Walker 1998). With time, this leads to large differences in Os isotopic compositions between old continental crust and mantle depleted in the Archean or Proterozoic. Thus, contamination of magmas by old continental crustal material versus old lithospheric mantle can be detected. The low ${ }^{187} \mathrm{Os} /{ }^{188} \mathrm{Os}_{\mathrm{i}}$ ratios observed in the most primitive transitional basalts indicate that the continental crust played a subordinate role in the genesis of these rocks. In contrast, the more radiogenic ${ }^{187} \mathrm{Os} /{ }^{188} \mathrm{Os}_{\mathrm{i}}$ ratios observed in the tholeiitic basalts suggest a crustal input in their genesis.

The presence of both low and high $\mathrm{Pb}$ isotope ratios in the intermediate and more evolved rocks of Mailaka offers no unique explanation for their genesis. Consideration of the geology of the centralwestern sector of Madagascar suggests that the Mailaka igneous rocks penetrated Late Proterozoic and Late Archean to Early Proterozoic crust. This can include a very wide range of possible contaminants, from mafic to silicic, low to high metamorphic grade, and so forth (de Wit 2003). The high $\mathrm{Pb}$ isotopic ratios of the intermediate (except for M160) and evolved rocks suggest that crust with high $\mathrm{U} / \mathrm{Pb}$ and $\mathrm{Th} / \mathrm{Pb}$ would be the most likely contaminants. In contrast, the low $\mathrm{Pb}$ isotopic ratios of andesite M160 would reflect a crustal contaminant of different composition (and perhaps age). We consider old, high-grade metamorphic rocks (e.g., granulites and amphibolites) to be suitable contaminants for the genesis of andesite M160. Such contaminants must be characterized by low $\mathrm{U} / \mathrm{Pb}$ and $\mathrm{Th} / \mathrm{Pb}$ values and be able to melt to at least small extents rather easily. 
Table 2. Energy-Constrained Assimilation and Fractional Crystallization (Spera and Bohrson 2001) Parameters for Intermediate-Evolved Rocks and Potential Contaminants (Lower and Upper Crust)

\begin{tabular}{|c|c|c|c|}
\hline Parameter & Upper crust & Lower crust & \\
\hline $\begin{array}{l}\text { Temperature }\left({ }^{\circ} \mathrm{C}\right) \text { : } \\
\text { Magma liquidus } \\
\text { Magma, initial } \\
\text { Assimilant liquidus } \\
\text { Assimilant, initial } \\
\text { Solidus } \\
\text { Equilibration } \\
\text { Crystallization enthalphy }(\mathrm{J} / \mathrm{kg}) \\
\text { Isobaric specific heat of magma }(\mathrm{J} / \mathrm{kg} \text { per } \mathrm{K}) \\
\text { Fusion enthalpy }(\mathrm{J} / \mathrm{kg}) \\
\text { Isobaric specific heat of assimilant }(\mathrm{J} / \mathrm{kg} \text { per } \mathrm{K})\end{array}$ & $\begin{array}{r}1280 \\
1280 \\
1000 \\
300 \\
900 \\
980 \\
396,000 \\
1484 \\
270,000 \\
1370\end{array}$ & $\begin{array}{r}1320 \\
1320 \\
1100 \\
600 \\
950 \\
980 \\
396,000 \\
1484 \\
354,000 \\
1388\end{array}$ & \\
\hline Compositional parameter & ${ }^{87} \mathrm{Sr} /{ }^{86} \mathrm{Sr}$ & ${ }^{206} \mathrm{~Pb} /{ }^{204} \mathrm{~Pb}$ & ${ }^{207} \mathrm{~Pb} /{ }^{204} \mathrm{~Pb}$ \\
\hline $\begin{array}{l}\text { Tholeiitic basalt M129: } \\
\text { Magma initial concentration }(\mu \mathrm{g} / \mathrm{g}) \\
\text { Magma isotope ratio } \\
\text { Magma trace element distribution } \\
\text { coefficient }\end{array}$ & $\begin{array}{r}416.7046\end{array}$ & $\begin{array}{l}1.8 \\
17.618\end{array}$ & $\begin{array}{c}1.8 \\
15.530\end{array}$ \\
\hline $\begin{array}{l}\text { Assimilant (upper crust): } \\
\text { Initial concentration }(\mu \mathrm{g} / \mathrm{g}) \\
\text { Isotope ratio } \\
\text { Trace element distribution coefficient }\end{array}$ & $\begin{array}{l}293 \\
.7423 \\
2.5\end{array}$ & $\begin{array}{l}23.1 \\
19.543 \\
.4\end{array}$ & $\begin{array}{c}23.1 \\
15.737 \\
.4\end{array}$ \\
\hline $\begin{array}{l}\text { Assimilant (lower crust): } \\
\text { Initial concentration }(\mu \mathrm{g} / \mathrm{g}) \\
\text { Isotope ratio } \\
\text { Trace element distribution coefficient }\end{array}$ & $\begin{array}{l}384 \\
.7318 \\
1.50\end{array}$ & $\begin{array}{l}4.0 \\
14.806 \\
.25\end{array}$ & $\begin{array}{c}4.0 \\
14.972 \\
.25\end{array}$ \\
\hline
\end{tabular}

Note. Thermodynamic parameters are from Spera and Bohrson (2001). Sr and Pb distribution coefficients are from the Geochemical Earth Reference Model database (http://earthref.org/GERM/). Upper-crust assimilant is represented by granite from Dharwar craton (Taylor et al. 1984). Lower-crust assimilant is represented by charnockite from Mozambique belt of Tanzania (Möller et al. 1998).

Origin of the Transitional Series. The transitional basalts have low abundances of $\mathrm{Nb}, \mathrm{Ta}, \mathrm{Zr}$, and $\mathrm{Hf}$ (e.g., $\mathrm{Nb} 2-8 \mu \mathrm{g} / \mathrm{g}$; $\mathrm{Zr}<150 \mu \mathrm{g} / \mathrm{g}$; tables A1-A5) and low $\mathrm{La}_{\mathrm{n}} / \mathrm{Yb}_{\mathrm{n}}(3-2.9)$ and $\mathrm{La}_{\mathrm{n}} / \mathrm{Nd}_{\mathrm{n}}(0.6-0.9)$, where the subscript $\mathrm{n}$ means chondrite normalized. In the primitive-mantle-normalized patterns (fig. $8 \mathrm{~A}$ ) the abundance of many elements is similar to those of Indian MORB except for $\mathrm{Rb}, \mathrm{Ba}$, and $\mathrm{Sr}$; also, the patterns are steeper from $\mathrm{Gd}$ to $\mathrm{Lu}$ than found in most Indian (or other) MORB. The selective enrichment of $\mathrm{Rb}, \mathrm{Ba}$, and $\mathrm{Sr}$ in the transitional basalts could indicate secondary alteration processes, but weight loss on ignition (LOI) values are relatively low in these samples. In the $\varepsilon \mathrm{Nd}_{\mathrm{i}}$ versus $\mathrm{MgO}$ diagram (fig. 9) the transitional basalts show no covariation, suggesting that broadly closed-system fractional crystallization prevailed over crustal assimilation. The low ${ }^{187} \mathrm{Os} /{ }^{188} \mathrm{Os}_{\mathrm{i}}$ ratios support this interpretation. Melluso et al. (2001) argued that the transitional basalts were likely generated by low degrees of partial melting $(2.5 \%-5 \%)$ of a depleted, MORB-like source that started to melt in the garnet stability field and ended in the spinel field. Positive values of $\gamma_{\mathrm{Os}}(+9.9$ to +10.6$)$ and $\varepsilon \mathrm{Nd}_{\mathrm{i}}$ in the transitional basalts rule out the involvement of substantial amounts of incompatible-elementenriched continental lithospheric mantle $\left(\gamma_{\mathrm{Os}}<0\right.$ to +1.6; Shirey and Walker 1998) in their genesis.

Origin of the Tholeiitic Series. The tholeiitic series shows large variations in $\mathrm{Pb}, \mathrm{Nd}$, and $\mathrm{Sr}$ isotopic ratios. This excludes the possibility that their range of elemental compositions is solely a result of closed-system fractional crystallization of basic parental magmas. The relatively high concentrations of incompatible elements typically enriched in the crust, such as $\mathrm{Rb}, \mathrm{Ba}$, and the light lanthanides (LREEs) in the picritic basalts to rhyodacites clearly indicate the involvement of a crustal component. The tholeiitic basalts have low $\mathrm{TiO}_{2}<1.43 \mathrm{wt} \%$; table $\mathrm{A} 1$ ) and $\mathrm{Nb}$ contents and high $\mathrm{La} / \mathrm{Nb}$ (1.52.6), are relatively LREE enriched $\left(\mathrm{La}_{\mathrm{n}} / \mathrm{Nd}_{\mathrm{n}}=1-\right.$ 1.4) and have peaks at $\mathrm{Ba}$ and $\mathrm{Sr}$ in the primitivemantle-normalized patterns (fig. 8B). These features, combined with low $\varepsilon \mathrm{Nd}_{\mathrm{i}}$ and relatively high ${ }^{187} \mathrm{Os} /{ }^{188} \mathrm{Os}_{\mathrm{i}}$ are compatible with high degrees of partial melting $(5 \%-7 \%)$ of a source enriched with a crustal component (Melluso et al. 2001).

The rhyodacitic unit in the upper part of the Mai- 

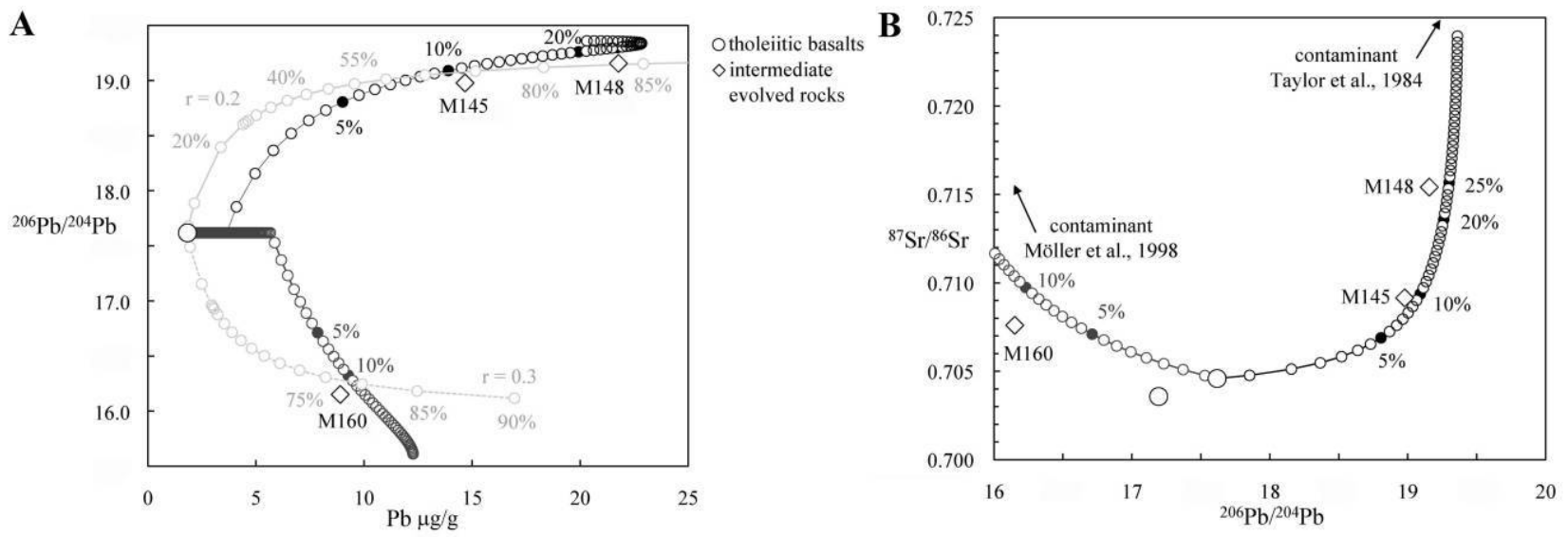

Figure 10. ${ }^{206} \mathrm{~Pb} /{ }^{204} \mathrm{~Pb}$ versus $\mathrm{Pb}(\mu \mathrm{g} / \mathrm{g})(A)$ and ${ }^{206} \mathrm{~Pb} /{ }^{204} \mathrm{~Pb}$ versus ${ }^{87} \mathrm{Sr} /{ }^{86} \mathrm{Sr}(B)$ with energy-constrained-assimilationfractional-crystallization (EC-AFC) vectors calculated using the code of Spera and Bohrson (2001). In addition, $A$ includes AFC curves (light gray) calculated using the equation of DePaolo (1981). Numbers on the AFC curves indicate the residual liquid fraction. End-member compositions are given in table 2.

laka sequence has inherited older zircons, peraluminous chemistry (with the consequent presence of cordierite phenocrysts), high $\mathrm{Pb}$ and Sr isotopic ratios, and low $\varepsilon \mathrm{Nd}_{\mathrm{i}}$. These features strongly suggest that the rhyodacites are generated by magmas contaminated by peraluminous melts from basement rocks. The high $\mathrm{Zr}, \mathrm{Y}$, and heavy lanthanide (HREE) content of the rhyodacites (table A5, in the online edition or from the Journal of Geology office) exclude the hypothesis that the rhyodacites are products of crustal melting, with or without the presence of residual garnet (Melluso et al. 2001). The most plausible petrogenetic process to generate the evolved rocks is, therefore, prolonged fractional crystallization, starting from a basaltic parental magma, with coupled assimilation of wall rock (assimilation and fractional crystallization [AFC]). Modeling was performed using the energy-constrained-AFC (EC-AFC) model of Spera and Bohrson (2001) and the AFC equations of DePaolo (1981). The thermal parameters are those used by Spera and Bohrson (2001) for typical upper and lower crust (table 2). The composition of the contaminant used in the EC-AFC and standard AFC model was assumed to be that of a granite from the Dharwar craton of southern India (Taylor et al. 1984). The results of our EC-AFC modeling for the intermediate to evolved rocks are displayed in figures $6 \mathrm{~A}$, $10 A$, and $10 B$. The EC-AFC vectors indicate $25 \%$ assimilation of upper crust in the genesis of the rhyodacites with a rate of assimilation $(r)$ of 0.35 and $\sim 11 \%$ assimilation with $r=0.18$ for the genesis of the andesites. The AFC equations of DePaolo (1981) indicate that the rhyodacites could be derived by $\sim 85 \%$ fractional crystallization coupled with $\sim 20 \%$ assimilation of upper crust. These results are comparable with those obtained in the ECAFC model and with those of Melluso et al. (2001, 2003). In contrast, the isotopic composition of andesite M160 excludes the involvement of a similar Archean granite contaminant in its genesis. To model the genesis of M160, we used a charnockite from the Pan-African Belt of Tanzania (Möller et al. 1998) as contaminant. Using the EC-AFC lower crust parameters (table 2), the andesite M160 contains $\sim 8 \%$ of assimilated lower crust with $r=$ 0.1 . We chose a granite of the Dharwar craton and a charnockite of the Tanzanian Belt as the closest representatives of the upper and lower crustal basement of Madagascar, respectively, because no bulkrock $\mathrm{Pb}$ isotopic data are available for the Madagascan basement rocks.

Comparison with Other Silicic Rocks of the Madagascan LIP. Silicic rocks also crop out in other parts of the island, although they are volumetrically subordinate to basaltic rocks. Many outcrops of silicic rocks are found along the eastern coast (Sambava, Tamatave, Vatomandry, and Mananjary districts), in the Antampombato-Ambatovy intrusion and the Volcan de l'Androy complex. The Sambava and Tamatave silicic rocks (Melluso et al. 2009) have $\mathrm{TiO}_{2}$ in the range $0.2-0.9 \mathrm{wt} \%$ and moderate to high $\mathrm{Zr}$ $(215-1250 \mu \mathrm{g} / \mathrm{g})$ and $\mathrm{Y}(30-125 \mu \mathrm{g} / \mathrm{g})$ contents. They are LREE enriched, with $\mathrm{La}_{\mathrm{n}} / \mathrm{Yb}_{\mathrm{n}}$ ranging from 4.1 to 9.7. Some rhyolites and trachytes are weakly peralkaline, but Melluso et al. (2009) did not consider them truly peralkaline. The Vatomandry-Mananjary silicic rocks are characterized by moderate to 

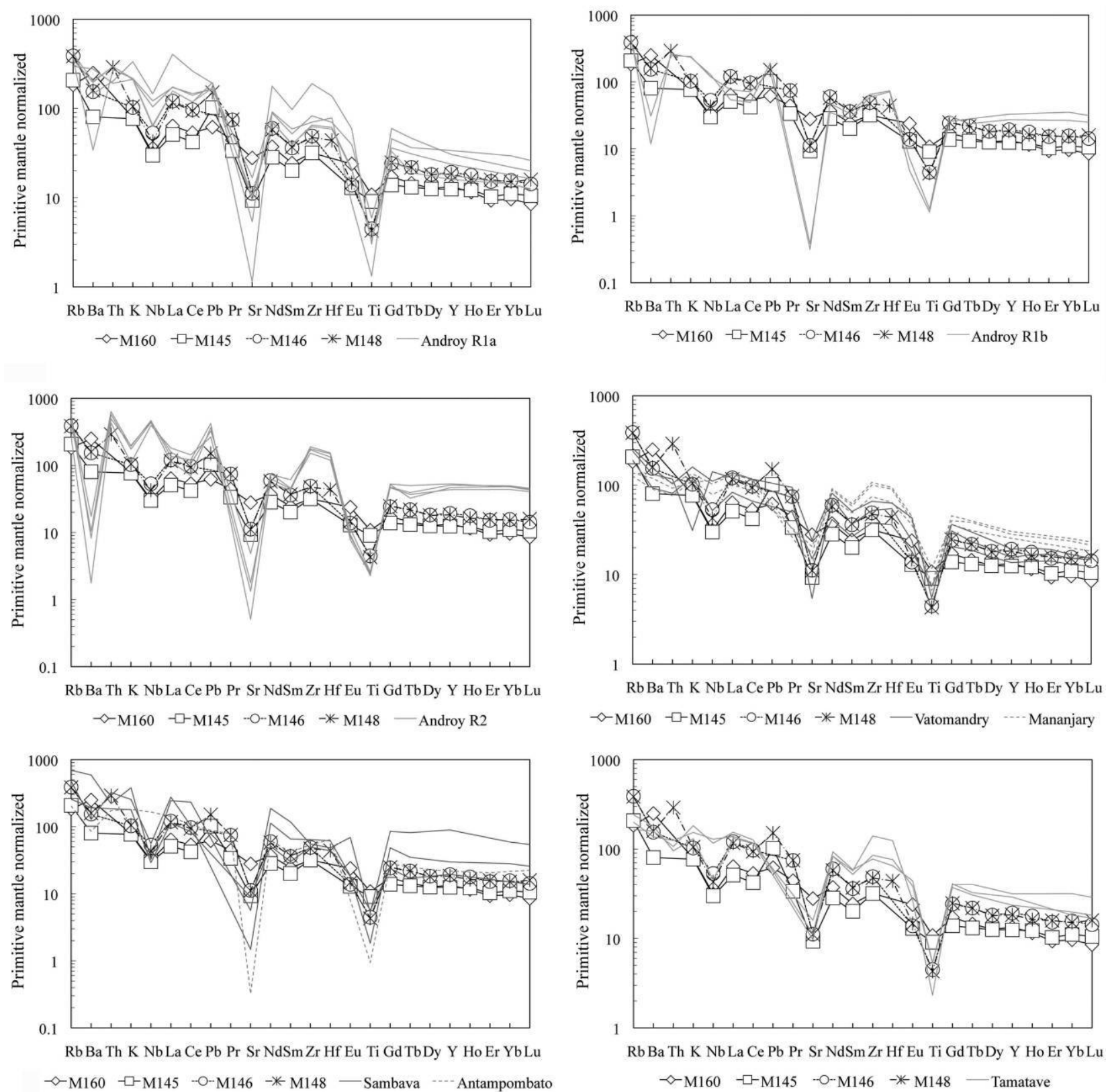

Figure 11. Primitive mantle-normalized incompatible element patterns for Cretaceous silicic rocks of Madagascar. Literature data are from Melluso et al. $(2005,2009)$ and Mahoney et al. (2008).

high $\mathrm{TiO}_{2}(0.62-1.36 \mathrm{wt} \%), \mathrm{Nb}(24-75 \mu \mathrm{g} / \mathrm{g}), \mathrm{Y}(61-$ $102 \mu \mathrm{g} / \mathrm{g})$, and $\mathrm{Zr}(308-906 \mu \mathrm{g} / \mathrm{g})$ contents and are LREE enriched, with $\mathrm{La}_{\mathrm{n}} / \mathrm{Yb}_{\mathrm{n}}$ of 5.0-8.2. The Vatomandry silicic rocks have lower $\varepsilon \mathrm{Nd}_{\mathrm{i}}(-2.5$ to -5.6) and more radiogenic ${ }^{87} \mathrm{Sr} /{ }^{86} \mathrm{Sr}_{\mathrm{i}}(0.70552$ to 0.70833) than the Mananjary silicic rocks $\left(\varepsilon \mathrm{Nd}_{\mathrm{i}}=0.8-2.6{ }^{87} \mathrm{Sr} /{ }^{86} \mathrm{Sr}_{\mathrm{i}}=0.70390-0.70522 ;\right.$ Melluso et al. 2009). Mahoney et al. (2008) identified two groups of rhyolites in the Volcan de l'Androy complex: (1) group R1 has variable Nb (27-105 $\mu \mathrm{g}$ / $\mathrm{g}), \mathrm{Y}(40-157 \mu \mathrm{g} / \mathrm{g})$, and $\mathrm{Zr}(331-1598 \mu \mathrm{g} / \mathrm{g})$; low $\varepsilon \mathrm{Nd}_{\mathrm{i}}$ $(-7.5$ to -17.3$)$; and high ${ }^{87} \mathrm{Sr} /{ }^{86} \mathrm{Sr}_{\mathrm{i}},{ }^{206} \mathrm{~Pb} /{ }^{204} \mathrm{~Pb}_{\mathrm{i}}$, ${ }^{207} \mathrm{~Pb} /{ }^{204} \mathrm{~Pb}_{\mathrm{i}}$, and ${ }^{208} \mathrm{~Pb} /{ }^{204} \mathrm{~Pb}_{\mathrm{i} ;}$ (2) group $\mathrm{R} 2$ is formed also by peralkaline rhyolites, and has higher Th, $\mathrm{Nb}, \mathrm{Ta}, \mathrm{Zr}, \mathrm{Hf}, \mathrm{Y}$, and HREE contents; higher $\varepsilon \mathrm{Nd}_{\mathrm{i}}$ $(-2.0$ to -2.5$)$; and lower ${ }^{208} \mathrm{~Pb} /{ }^{204} \mathrm{~Pb}_{\mathrm{i}}$. The Antampombato rhyolitic dikes (Melluso et al. 2005) are slightly peralkaline, have relatively high $\mathrm{Zr}$ and $\mathrm{Nb}$ (479-752 $\mu \mathrm{g} / \mathrm{g}$ and $69-76 \mu \mathrm{g} / \mathrm{g}$, respectively) contents and are LREE enriched $\left(\mathrm{La}_{\mathrm{n}} / \mathrm{Yb}_{\mathrm{n}}=6.5\right)$. Ini- 
A

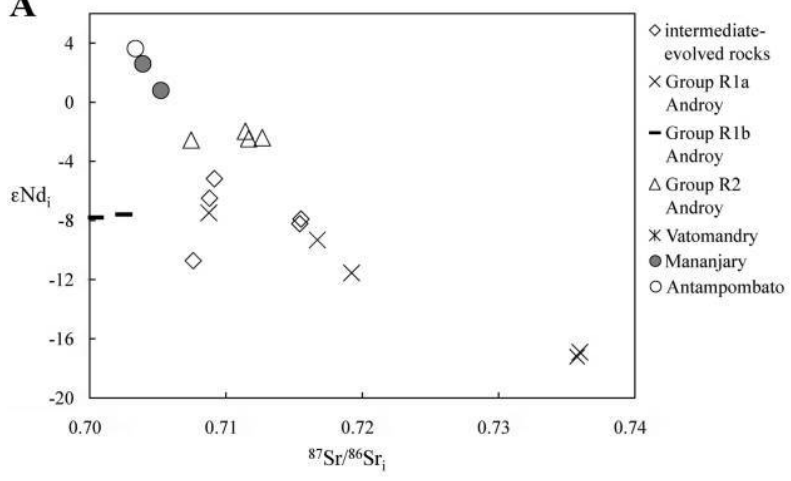

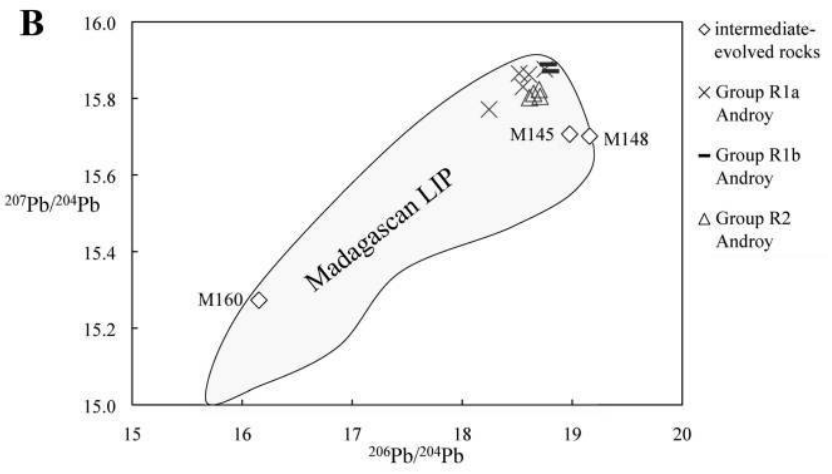

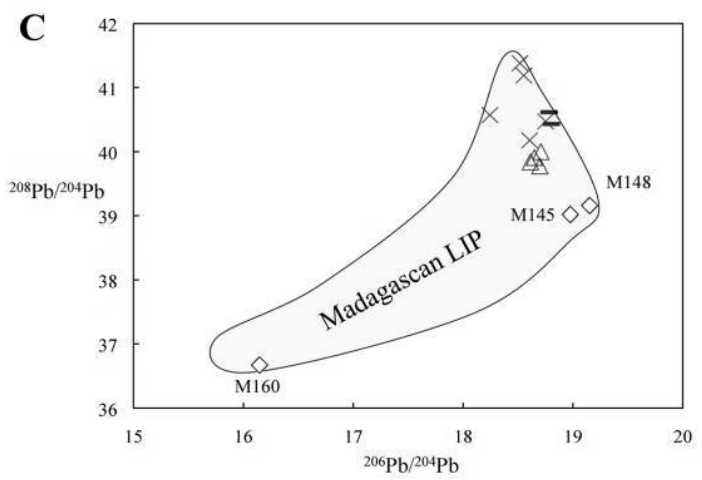

Figure 12. $\mathrm{Sr}, \mathrm{Nd}$, and $\mathrm{Pb}$ isotopic compositions of Cretaceous silicic rocks of Madagascar. The data for other silicic rocks of the province are from Melluso et al. $(2005,2009)$ and Mahoney et al. (2008). The Madagascan large igneous province (LIP) field is from Mahoney et al. (1991, 2008), Storey et al. (1997) and Melluso et al.(2001, 2002, 2003, 2005).

tial ${ }^{87} \mathrm{Sr} /{ }^{86} \mathrm{Sr}$ and ${ }^{143} \mathrm{Nd} /{ }^{144} \mathrm{Nd}$ of Antampombato rhyolites are 0.70389 and $0.51271\left(\varepsilon \mathrm{Nd}_{\mathrm{i}}=+3.7\right)$, respectively. Comparisons of the incompatible element abundances and isotopic compositions of the intermediate and evolved rocks of Mailaka with those of other evolved rocks of the Madagascan province are shown in figure 11. Elements such as $\mathrm{Zr}, \mathrm{Nb}$, and $\mathrm{Hf}$ and the heavy lanthanides are generally less abundant in the intermediate and evolved rocks of Mailaka. In the ${ }^{87} \mathrm{Sr} /{ }^{86} \mathrm{Sr}_{\mathrm{i}}$ versus ${ }^{143} \mathrm{Nd} /{ }^{144} \mathrm{Nd}_{\mathrm{i}}$ diagram (fig. 12A), data for the intermediate and evolved rocks of Mailaka plot far from the fields defined by the Vatomandry, Mananjary, Antampombato, and Androy (group R2) silicic rocks and only partially fill the field defined by the Androy (group $\mathrm{R} 1$ ) silicic rocks. In $\mathrm{Pb}-\mathrm{Pb}$ isotope space (fig. 12B, 12C), the intermediate and evolved rocks of Mailaka form an isotopically distinct group. The strong chemical and isotopic differences between the intermediate and evolved rocks of Mailaka and the other silicic rocks of the Mada- gascar LIP exclude any similar petrogenetic evolution.

\section{Conclusions}

$\mathrm{U}-\mathrm{Pb}$ zircon ages for rhyodacites of the Mailaka lava succession demonstrate that the silicic volcanism in this region is part of the Madagascan LIP and that the time of eruption of the Mailaka lava sequence was short. Trace element and isotope data indicate that the transitional basalts were generated by low-degree melting of an incompatibleelement-depleted, broadly MORB-like mantle source. The influence of crustal contamination on isotopic compositions observed within the transitional basalts is negligible. In contrast, the incompatible element trends and isotopic ratios observed within the tholeiitic basalts are the result of assimilation of continental crust. The high $\gamma$ Os and low $\varepsilon \mathrm{Nd}_{\mathrm{i}}$ values support this interpretation. The variations in $\mathrm{Sr}, \mathrm{Nd}$, and $\mathrm{Pb}$ isotope ratios in the an- 
desites and rhyodacites clearly show that these rocks evolved under open-system conditions. In addition, chemical and isotopic differences between the tholeiitic andesite M160 and the other evolved rocks indicate a distinct crustal end-member in its genesis. Andesite M160 can be modeled by opensystem processes involving fractional crystallization of basic magma and assimilation of old lower crust, whereas the rhyodacites appear to have interacted predominantly with upper crustal materials. Therefore, interaction of mantle-derived magmas with differently reworked portions of the Madagascan continental crust was a significant petrogenetic process. This does not mean (or imply) that interaction occurred at different levels in the crust, given the folded and thrusted structure of the Madagascan basement. Our data provide further evidence that flood basalt sequences on similar crustal domains (e.g., the Deccan Traps) may well have experienced interaction with crustal materials of different ages and petrogenetic histories (cf. Peng et al. 1994; Melluso et al. 2006a).

\section{A C K N O W LE D G M E N T S}

We thank L. Fedele for his help with the isotope work at the University of Hawaii at Manoa School of Ocean and Earth Science and Technology, P. Brotzu for advice, and L. Franciosi for sharing his experience in zircon handpicking. Discussions with A. Saunders on the contents of an early version were much appreciated. The thoughtful journal reviews of L. Ashwal and R. Tucker were very useful for the preparation of a revised version. Grants for this project were provided by MIUR (Ministero dell'Istruzione, dell'Università e della Ricerca) to L. Melluso.

\section{R E F E R E N C E S C I T E D}

Anders, E., and Grevesse, N. 1989. Abundances of the elements: meteoritic and solar. Geochim. Cosmochim. Acta 53:197-214.

Ashwal, L. D., and Tucker, R. D. 1997. Geology of Madagascar: a brief outline. Gondwana Res. 2:335-339.

Becker, H.; Horan, M. F.; Walker, R. J.; Gao, S.; Lorand, J.-P.; and Rudnick, R. L. 2006. Highly siderophile element composition of the Earth's primitive upper mantle: constraints from new data on peridotite massifs and xenoliths. Geochim. Cosmochim. Acta 70: 4528-4550.

Besairie, H. 1964. Geological map of Madagascar. Scale $1: 1,000,000$. Service Géologique de Madagascar, Tananarive.

Besairie, H., and Collignon, M. 1972. Géologie de Madagascar. I. Les terraines sédimentaires. Ann. Geol. Madag. 35:553.

Boynton, W. V. 1984. Cosmochemistry of the rare earth elements: meteorite studies. In Henderson, P., ed. Rare earth element geochemistry. Amsterdam, Elsevier, p. 63-114.

Chazey, W. J., III, and Neal, C. R. 2004. Large igneous province magma petrogenesis from source to surface: platinum-group element evidence from Ontong Java Plateau basalts recovered during ODP legs 130 and 192. Geol. Soc. Lond. Spec. Publ. 229:219-238.

- 2005. Platinum-group element constraints on source composition and magma evolution of the Kerguelen Plateau using basalts from ODP leg 183. Geochim. Cosmochim. Acta 69:4685-4701.

Cox, R.; Armstrong, R. A.; and Ashwal, L. D. 1998. Sedimentology, geochronology and provenance of the Proterozoic Itremo Group, central Madagascar, and im- plications for pre-Gondwana palaeogeography. I. Geol. Soc. Lond. 155:1009-1024.

Crocket, J. H., and Paul, D. K. 2004. Platinum-group elements in Deccan mafic rocks: a comparison of suites differentiated by Ir content. Chem. Geol. 208:273291.

DePaolo, D. J. 1981. Trace element and isotopic effects of combined wallrock assimilation and fractional crystallization. Earth Planet. Sci. Lett. 53:189-202.

de Wit, M. J. 2003. Madagascar: heads it's a continent, tails it's an island. Annu. Rev. Earth Planet. Sci. 31: 213-248.

Dostal, J.; Dupuy, C.; Nicollet, C.; and Cantagrel, J. M. 1992. Geochemistry and petrogenesis of upper Cretaceous basaltic rocks from southern Madagascar. Chem. Geol. 97:199-218.

Escrig, S.; Capmas, F.; Dupré, B.; and Allègre, C. J. 2004. Osmium isotopic constraints on the nature of the DUPAL anomaly from Indian mid-ocean-ridge basalts. Nature 431:59-63.

Gannoun, A.; Burton, K. W.; Parkinson, I. J.; Alard, O.; Schiano, P.; and Thomas, L. E. 2007. The scale and origin of the osmium isotope variations in mid-ocean ridge basalts. Earth Planet. Sci. Lett. 259:541-556.

Handke, M.; Tucker, R. D.; and Ashwal, L. D. 1999. Neoproterozoic continental arc magmatism in west-central Madagascar. Geology 27:351-354.

Hart, S. R. 1984. A large-scale isotope anomaly in the Southern Hemisphere mantle. Nature 309:753-757.

Hauri, E. H., and Hart, S. R. 1997. Rhenium abundances and systematics in oceanic basalts. Chem. Geol. 139: 185-205.

Horstwood, M. S. A.; Foster, G. L.; Parrish, R. R.; Noble, S. R.; and Nowell, G. M. 2003. Common-Pb corrected 
in situ U-Pb accessory mineral geochronology by LAMC-ICP-MS. I. Anal. At. Spectrom. 18:837-846.

Janney, P. E.; le Roex, A. P.; and Carlson, R. W. 2005. Hafnium isotope and trace element constraints on the nature of mantle heterogeneity beneath the central southwest Indian Ridge $\left(13^{\circ} \mathrm{E}\right.$ to $\left.47^{\circ} \mathrm{E}\right)$. L. Petrol. 46 : 2427-2464.

Ketchum, J. W. F.; Jackson, S. E.; Culshaw, N. G.; and Barr, S. M. 2001. Depositional and tectonic setting of the Paleoproterozoic Lower Aillik Group, Makkovik Province, Canada: evolution of a passive margin foredeep sequence based on petrochemistry and $\mathrm{U}-\mathrm{Pb}$ (TIMS and LAM-ICP-MS) geochronology. Precambrian Res. 105:331-356.

Kröner, A.; Hegner, E.; Collins, A. S.; Windley, B. F.; Brewer, T. S.; Razakamanana, T.; and Pidgeon, R. T. 2000. Age and magmatic history of the Antananarivo Block, Central Madagascar, as derived from zircon geochronology and $\mathrm{Nd}$ isotopic systematics. Am. I. Sci. 300:251-288.

Ludwig, K. R. 2000. Isoplot: a geochronological toolkit for Microsoft Excel. Spec. Publ.1a:53. Berkeley, CA, Berkeley Geochronological Center.

Lyubetskaya, T., and Korenaga, J. 2007. Chemical composition of Earth's primitive mantle and its variance: 1. Method and results. J. Geophys. Res. 112:1-21.

Mahoney, J. J.; le Roex, A. P.; Peng, Z. X.; Fisher, R. L.; and Natland, J. H. 1992. Southwestern limit of Indian Ocean ridge mantle and the origin of $10 \mathrm{w}{ }^{206} \mathrm{~Pb} /{ }^{204} \mathrm{~Pb}$ MORB: isotope systematics of the central southwest Indian Ridge $\left(17^{\circ}-50^{\circ} \mathrm{E}\right)$. L. Geophys. Res. 97:19,77119,790 .

Mahoney, J. J.; Natland, J. H.; White, W. M.; Poreda, R.; Bloomer, S. H.; Fisher R. L.; and Baxter, A. N. 1989. Isotopic and geochemical provinces of the western Indian Ocean spreading centers. L. Geophys. Res. 94: 4033-4052.

Mahoney, J. J.; Nicollet, C.; and Dupuy, C. 1991. Madagascar basalts: tracking oceanic and continental sources. Earth Planet. Sci. Lett. 104:350-363.

Mahoney, J. J.; Saunders, A. D.; Storey, M.; and Randriamantenasoa, A. 2008. Geochemistry of the Volcan de l'Androy basalt-rhyolite complex, Madagascar Cretaceous igneous province. L. Petrol. 49:1069-1096.

Maier, W. D.; Barnes, S.-J.; and Marsh, J. S. 2003. The concentrations of the noble metals in Southern African flood-type basalts and MORB: implications for petrogenesis and magmatic sulphide exploration. Contrib. Mineral. Petrol. 146:44-61.

Meisel, T.; Fellner, N.; and Moser, J. 2003. A simple procedure for the determination of platinum group elements and rhenium $(\mathrm{Ru}, \mathrm{Rh}, \mathrm{Pd}, \mathrm{Re}, \mathrm{Os}, \mathrm{Ir}$ and $\mathrm{Pt})$ using ID-ICP-MS with an inexpensive on-line matrix separation in geological and environmental materials. L. Anal. At. Spectrom. 18:720-726.

Meisel, T.; Moser, J.; Fellner, N.; Wegscheider, W.; and Schoenberg, R. 2001. Simplified method for the determination of $\mathrm{Ru}, \mathrm{Pd}, \mathrm{Re}, \mathrm{Os}$, Ir and $\mathrm{Pt}$ in chromitites and other geological materials by isotope dilution ICPMS and acid digestion. Analyst 126:322-328.
Meyzen, C. M.; Ludden, J. N.; Humler, E.; Luais, B.; Toplis, M. J.; Mevel, C.; and Storey, M. 2006. New insights into the origin and distribution of DUPAL isotope anomaly in the Indian Ocean mantle from MORB of southwest Indian Ridge. Geochem. Geophys. Geosyst. 6:Q11K11, doi:10.1029/2005GC000979.

Melluso, L.; Mahoney, J. J.; and Dallai, L. 2006a. Mantle sources and crustal input in Mg-rich Deccan Trap basalts from Gujarat (India). Lithos 89:259-274.

Melluso, L.; Morra, V.; Brotzu, P.; D'Antonio, M.; and Bennio, L. 2002. Petrogenesis of the Late Cretaceous tholeiitic magmatism in the passive margins of northeastern Madagascar. In Menzies, M. A.; Ebinger, C. J.; and Baker, J., eds. Volcanic rifted margins. Geol. Soc. Am. Spec. Pap. 362:83-98.

Melluso, L.; Morra, V.; Brotzu, P.; Franciosi, L.; Petteruti Lieberknecht, A. M.; and Bennio, L. 2003. Geochemical provinciality in the Cretaceous magmatism of northern Madagascar, and mantle source implications. I. Geol. Soc. Lond. 160:477-488.

Melluso, L.; Morra, V.; Brotzu, P.; and Mahoney, J. J. 2001. The Cretaceous igneous province of central-western Madagascar: evidence for heterogeneous mantle sources, crystal fractionation and crustal contamination. I. Petrol. 42:1249-1278.

Melluso, L.; Morra, V.; Brotzu, P.; Razafiniparany, A.; Ratrimo, V.; and Razafimahatratra, D. 1997. Geochemistry and Sr-isotopic composition of the Late Cretaceous flood basalt sequence of northern Madagascar: petrogenetic and geodynamic implications. I. Afr. Earth Sci. 34:371-390.

Melluso, L.; Morra, V.; Brotzu, P.; Tommasini, S.; Renna, M. R.; Duncan, R. A.; Franciosi, L.; and d'Amelio, F. 2005. Geochronology and petrogenesis of the Cretaceous Antampombato-Ambatovy complex and associated dyke swarm, Madagascar. I. Petrol. 46: $1963-$ 1996.

Melluso, L.; Morra, V.; and Fedele, L. 2006b. An overview of phase chemistry and magmatic evolution in the Cretaceous flood basalt province of northern Madagascar. Per. Mineral. 75:174-188.

Melluso, L.; Sheth, H. C.; Mahoney, J. J.; Morra, V.; Petrone, C. M.; and Storey, M. 2009. Correlations between silicic volcanic rocks of the St Mary's Islands (southwestern India) and eastern Madagascar: implications for Late Cretaceous India-Madagascar reconstructions. I. Geol. Soc. Lond. 166:281-292.

Möller, A.; Mezger, K.; and Schenk, V. 1998. Crustal age domains and the evolution of the continental crust in the Mozambique Belt of Tanzania: combined Sm-Nd, $\mathrm{Rb}-\mathrm{Sr}$ and $\mathrm{Pb}-\mathrm{Pb}$ isotopic evidence. L. Petrol. 39:749783.

Pande, K.; Sheth, H. C.; and Bhutani, R. 2001. ${ }^{40} \mathrm{Ar}^{-39} \mathrm{Ar}$ age of the St. Mary's Islands volcanics, southern India: record of the India-Madagascar break-up on the Indian subcontinent. Earth Planet. Sci. Lett. 193:39-46.

Peng, Z. X.; Mahoney, J. J.; Hooper, P. R.; Harris, C.; and Beane, J. E. 1994. A role for lower continental crust in flood basalt genesis? isotopic and incompatible element study of the lower six formations of the west- 
ern Deccan Traps; Geochim. Cosmochim. Acta 58: 267-288.

Piqué, A.; Laville, E.; Bignot, G.; Rabarimanana, M.; and Thounin, C. 1999. L'ouverture et le développement du bassin de Morondava (Madagascar) du Carbonifére supérieur au Jurassique moyen. Données stratigraphiques, sédimentaires, paléontologiques et structurales. I. Afr. Earth Sci. 28: 931-948.

Radhakhrishna, T.; Dallmeyer, R. D.; and Joseph, M. 1994. Palaeomagnetism and ${ }^{36} \mathrm{Ar} /{ }^{40} \mathrm{Ar}$ vs. ${ }^{39} \mathrm{Ar} /{ }^{40} \mathrm{Ar}$ isotope correlation ages of dyke swarms in central Kerala, India: tectonic implications. Earth Planet. Sci. Lett. 121: 213-226.

Radhakhrishna, T.; Maluski, H.; Mitchell, J. G.; and Joseph, M. 1999. ${ }^{40} \mathrm{Ar} /{ }^{39} \mathrm{Ar}$ and $\mathrm{K} / \mathrm{Ar}$ geochronology of the dykes from the south Indian granulite terrain. Tectonophysics 304:109-129.

Rehkämper, M., and Hofmann, A. W. 1997. Recycled ocean crust and sediment in Indian Ocean MORB. Earth Planet. Sci. Lett. 147: 93-106.

Reisberg, L., and Meisel, T. 2002. The Re-Os system: a review of analytical techniques. Geostand. Newsl. 26: 249-267.

Shirey, S. B., and Walker, R. J. 1998. The Re-Os isotope system in cosmochemistry and high-temperature geochemistry. Annu. Rev. Earth Planet. Sci. 26:423-500.

Sircombe, K. N. 2004. AgeDisplay: an Excel workbook to evaluate and display univariate geochronological data using binned frequency histograms and probability density distributions. Comput. Geosci. 30:2131.

Spera, F. J., and Bohrson, W. A. 2001. Energy-constrained open-system magmatic processes I: General model and energy-constrained assimilation and fractional crystallization (EC-AFC) formulation. I. Petrol. 41: 999-1018.

Storetvedt, M.; Mitchell, J. G.; Abranches, M. C.; Maaloe, S.; and Robin, G. 1992. The coast-parallel dikes of east Madagascar: age of intrusion, remagnetization and tectonic aspects. I. Afr. Earth Sci. 15:237-249.

Storey, M.; Mahoney, J. J.; and Saunders, A. D. 1997. Cretaceous basalts in Madagascar and the transition between plume and continental lithosphere mantle sources. In Mahoney, J. J., and Coffin, M. F. eds. Large igneous provinces: continental, oceanic and planetary flood volcanism. Am. Geophys. Union Geophys. Monogr. 100:95-122.

Storey, M.; Mahoney, J. J.; Saunders, A. D.; Duncan, R. A.; Kelley, S. P.; and Coffin, M. F. 1995. Timing of hot spot-related volcanism and the breakup of Madagascar and India. Science 267:52-855.
Taylor, P. N.; Chadwick, B.; Moorbath, S.; Ramakrishnan, M.; and Viswanathan, M. N. 1984. Petrography, chemistry and isotopic ages of Peninsular Gneiss, Dharwar acid volcanic rocks and the Chitradurga granite with special reference to the late Archean evolution of the Karnataka Craton, southern India. Precambrian Res. 23: 349-375.

Tiepolo, M. 2003. In situ Pb geochronology of zircon with laser ablation-inductively coupled plasma-sector field mass spectrometry. Chem. Geol. 199:159-177.

Todt, W.; Cliff, R. A.; Hanser, A.; and Hofmann, A. W. 1996. Evaluation of a ${ }^{202} \mathrm{~Pb}-{ }^{205} \mathrm{~Pb}$ double spike for highprecision lead isotopic analyses. In Basu, A., and Hart, S. R., eds. Earth processes: reading the isotopic code. Am. Geophys. Union Monogr. 95:429-437.

Torsvik, T. H.; Tucker, R. D.; Ashwal, L. D.; Carter, L. M.; Jamtveit, B.; Vidyadharan, K. T.; and Venkataramana, P. 2000. Late Cretaceous India-Madagascar fit and timing of break-up related magmatism. Terra Nova 12:220-224.

Torsvik, T. H.; Tucker, R. D.; Ashwal, L. D.; Eide, E. A.; Rakotosolofo, N. A.; and de Wit, M. J. 1998. Late Cretaceous magmatism of Madagascar: paleomagnetic evidence for a stationary hotspot. Earth Planet. Sci. Lett. 164:221-232.

Tucker, R. D.; Ashwal, L. D.; Handke, M. J.; Hamilton, M. A.; Le Grange, M.; and Rambeloson, R. A. 1999. $\mathrm{U}-\mathrm{Pb}$ geochronology and isotope geochemistry of the Archean and Proterozoic rocks of north-central Madagascar. I. Geol. 107:135-153.

van Achterbergh, E.; Ryan, C. G.; Jackson, S. E.; and Griffin, W. 2001. Data reduction software for LA-ICP-MS. In Sylvester, P. ed. Laser ablation-ICPMS in the earth science. Short course series 29. Quebec, Mineralogical Association of Canada, p. 239-243.

Vavra, G.; Gebauer, D.; Schmid, R.; and Compston, W. 1996. Multiple zircon growth and recrystallisation during polyphase Late Carboniferous to Triassic metamorphism in granulites of the Ivrea Zone (Southern Alps): an ion microprobe (SHRIMP) study. Contrib. Mineral. Petrol. 122:337-358.

Walker, R. J., and Morgan, J. W. 1989. Rhenium-osmium isotope systematics in carbonaceous chondrites. Science 243:519-522.

Wiedenbeck, M.; Alle, P.; Corfu, F.; Griffin, W. L.; Meier, M.; Ober, F.; Von Quadt, A.; Roddick, J. C.; and Spiegel, J. 1995. Three natural zircon standards for U-Th-Pb, Lu-Hf, trace element and REE analysis. Geostand. Newsl. 19:1-23. 